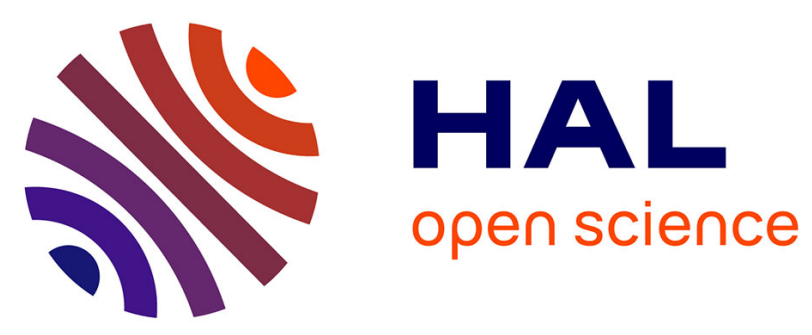

\title{
A Scalable Silicon Nanowires-Grown-On-Graphite Composite for High-Energy Lithium Batteries
}

Saravanan Karuppiah, Caroline Keller, Praveen Kumar, Pierre-Henri

Jouneau, Dmitry Aldakov, Jean-Baptiste Ducros, Gérard Lapertot, Pascale

Chenevier, Cédric Haon

\section{To cite this version:}

Saravanan Karuppiah, Caroline Keller, Praveen Kumar, Pierre-Henri Jouneau, Dmitry Aldakov, et al.. A Scalable Silicon Nanowires-Grown-On-Graphite Composite for High-Energy Lithium Batteries. ACS Nano, 2020, 14, pp.12006-12015. 10.1021/acsnano.0c05198 . cea-02942926

HAL Id: cea-02942926

https://hal-cea.archives-ouvertes.fr/cea-02942926

Submitted on 18 Sep 2020

HAL is a multi-disciplinary open access archive for the deposit and dissemination of scientific research documents, whether they are published or not. The documents may come from teaching and research institutions in France or abroad, or from public or private research centers.
L'archive ouverte pluridisciplinaire HAL, est destinée au dépôt et à la diffusion de documents scientifiques de niveau recherche, publiés ou non, émanant des établissements d'enseignement et de recherche français ou étrangers, des laboratoires publics ou privés. 


\title{
High silicon loading for high energy lithium batteries with an easy scalable silicon nanowires-grown-on-graphite composite
}

\author{
Saravanan Karuppiah, ${ }^{\mathrm{a}, \mathrm{b}}$ Caroline Keller, ${ }^{\mathrm{a}, \mathrm{b}}$ Praveen Kumar, ${ }^{\mathrm{c}}$ Pierre-Henri Jouneau, ${ }^{\mathrm{c}}$ Dmitry Aldakov, ${ }^{\mathrm{a}}$ \\ Jean-Baptiste Ducros, ${ }^{b}$ Gérard Lapertot, ${ }^{d}$ Pascale Chenevier*a and Cédric Haon*b \\ a Univ. Grenoble Alpes, CEA, CNRS, IRIG, SYMMES, STEP, 38000 Grenoble, France \\ b Univ. Grenoble Alpes, CEA, LITEN, DEHT, 38000 Grenoble, France \\ c Univ. Grenoble Alpes, CEA, IRIG, MEM, LEMMA, 38000 Grenoble, France \\ d Univ. Grenoble Alpes, CEA, IRIG, PHELIQS, IMAPEC, 38000 Grenoble, France
}

Silicon ( $\mathrm{Si}$ ) is the most promising anode candidate for the next generation of lithium-ion batteries but difficult to cycle due to its poor electronic conductivity and large volume change during cycling. Nanostructured Si-based materials allow high loading and cycling stability but remain a challenge for process and engineering. We prepare a Si nanowires-grown-on-graphite one-pot composite (Gt-SiNW) via a simple and scalable route. The uniform distribution of SiNW and the graphite flakes alignment prevent electrode pulverization and accommodate volume expansion during cycling, resulting in very low electrode swelling. Our designed nano-architecture delivers outstanding electrochemical performance with a capacity retention of $87 \%$ after 250 cycles at $2 \mathrm{C}$ rate with an industrial electrode density of $1.6 \mathrm{~g} \mathrm{~cm}^{-3}$. Full cells with NMC-622 cathode display a capacity retention of $70 \%$ over 300 cycles. This work provides insights into the fruitful engineering of active composites at the nanoand microscales to design efficient Si-rich anodes.

\section{Introduction}

Developing portable electronic devices and electric vehicles requires lithium-ion batteries (LIBs) with higher energy and power density, longer cycle life and competitive cost. ${ }^{1,2}$ As the energy density of graphite anodes is reaching its theoretical limit, LIBs must shift towards higher capacity anode materials. Silicon (Si) is the most promising, due to its low working voltage $\left(0.4 \mathrm{~V}\right.$ versus $\left.\mathrm{Li}^{+} / \mathrm{Li}^{2}\right)$ and high theoretical capacity $\left(3579 \mathrm{mAh} \mathrm{g}^{-1}\right) .^{3}$ Unfortunately, $\mathrm{Si}$ is suffering two main issues, i) a low electrical conductivity and, ii) a large volume change during lithiation. The former requires an electrode engineering with an electrical conductive network. The latter relates to bulk Si dramatic expansion when alloying with lithium, ${ }^{4,5}$ ultimately causing battery failure through mechanical degradation, contact loss and continuous formation of a solid electrolyte interphase (SEI). Nanostructured Si tolerates this volume change: Si nanowires (SiNWs), ${ }^{6}$ nanoparticles, ${ }^{7,8}$ nanotubes, ${ }^{9}$ porous $\mathrm{Si}^{10-12}$ core-shell structure ${ }^{13}$ show superior cycling stability.

Unfortunately, Si nanostructures alone cannot provide an areal capacity matching that of existing cathodes, ${ }^{14}$ due to very low accessible areal mass loading. Composites of Si and graphite (Gt) provide a good compromise as they attain tap densities ${ }^{14-16}$ of $1.6 \mathrm{~g} \mathrm{~cm}^{-3}$, fitting industrial needs. But for commercial application, they must surpass graphite in both specific capacity ( $372 \mathrm{mAh} \mathrm{g}^{-1}$ ) with a sufficient retention ( $80 \%$ at 500 cycles), and volumetric capacity $\left(550 \mathrm{mAh} \mathrm{cm}^{-3}\right)$ at a practical loading of $3 \mathrm{mAh} \mathrm{cm} \mathrm{cm}^{-2}$. Recent reports ${ }^{5,17-27}$ demonstrate Si nanolayer (5-6wt\% Si) or hierarchical Si hybrids (10-50 wt\% Si) embedded in a graphite/carbon matrix as a practical anode, with a reversible specific capacity of 500-600 mAh g ${ }^{-1}$ along with an initial Coulombic efficiency (ICE) of 63-93\%. However, commercialization of such anodes is still hindered by the insufficient impact on energy density due to 
their limited capacity and tap density, and by high cost production processes. To date, anodes with capacity above $1000 \mathrm{mAh} \mathrm{g}^{-1}$ are needed to increase significantly the energy density of LIB. ${ }^{28}$ Thus, we specifically design a Si nanowires-grown-on-graphite one-pot composite anode to fulfill all pre-cited criteria including an easy scalable approach.

Our unique architecture facilitates uniform distribution of $\mathrm{Si}$ on $\mathrm{Gt}$, controls the effective Si/Gt ratio, acts as a cushion to accommodate volume changes, and maintains the mechanical and electrical integrity of the electrode. Interestingly, a thin native organic shell grown around the SiNWs from the organosilane precursor during synthesis significantly lowers natural Si oxidation once in contact with air, improving the electrochemical performance. Gt-SiNW anodes exhibit a reversible capacity of $1000 \mathrm{mAh} \mathrm{g}^{-1}$ even with a loading of $2.7 \mathrm{mg} \mathrm{cm}^{-2}$ after 100 cycles at $0.2 \mathrm{C}$ rate. The full cell comprising NMC-622 and Gt-SiNW boasts a high energy density of $414 \mathrm{Wh} \mathrm{kg}^{-1}$ over 300 cycles with $70 \%$ capacity retention. Besides, Gt-SiNW electrodes swell by only $20 \%$ after 100 cycles, which is the lowest value reported so far in the literature. Using FIB-SEM cross sectional imaging, we inquire about the electrode morphology and swelling mechanisms and find an interesting synergy between the SiNW nanoporosity and the graphite flakes microstructure.
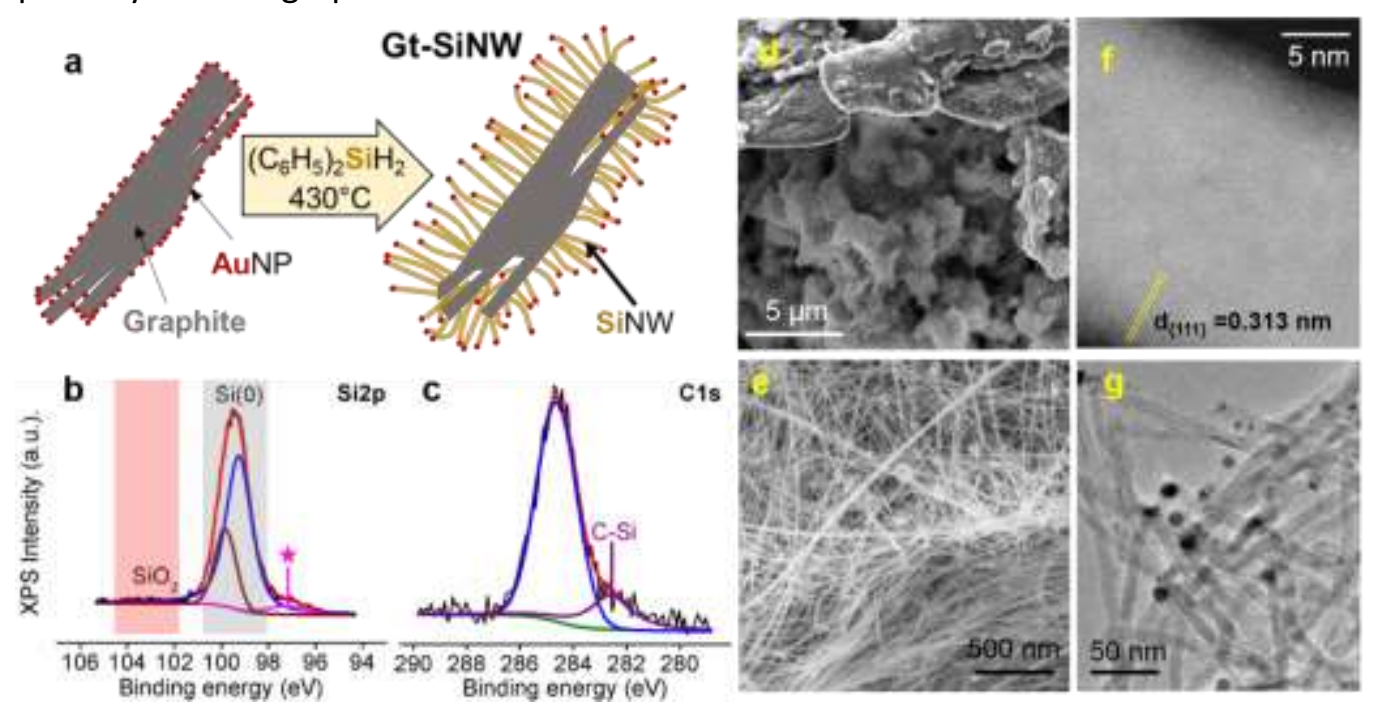

Figure 1. Characterization of Gt-SiNW. (a) Scheme representing the synthesis of SiNWs on graphite. (b and c) XPS deconvoluted spectra of Si2p (b) and C1s (c) orbitals of Gt-SiNW. $\left({ }^{*}\right)$ is attributed to plasmon loss from the metal Auf5/2 peak (Fig. S1). (d and e) Scanning electron microscopy (SEM), (f) scanning transmission electron microscopy (STEM) and $(g)$ transmission electron microscopy (TEM) images of GtSiNW.

\section{Results and discussion}

Fig. 1a schematically illustrates the SiNW growth process. First, 1-2 nm Au nanoparticles (NPs) are deposited on the surface of graphite microflakes in solution, by solvent evaporation. Then, SiNWs are grown from the gold catalyst at $430^{\circ} \mathrm{C}$ using diphenylsilane as Si source ${ }^{29}$ To target a specific capacity superior to $1000 \mathrm{mAh} / \mathrm{g}$, we synthesized a series of Gt-SiNW composites with Si content ranging from 20 to $40 \mathrm{wt} \%$. The as-synthesized materials are processed into electrodes using standard procedures and tested for cyclability in half-cell configuration at $0.2 \mathrm{C}$ rate. The optimal capacity and durability are obtained for the Gt-SiNW anode containing $32 \mathrm{wt} \% \mathrm{Si}$ (Fig. S2), which was thus selected in the present work. The one-pot synthesis is scalable, producing $1.2 \mathrm{~g}$ per batch in a small reactor $(150 \mathrm{~mL}$, 
Fig. S3), and simple, involving no stringent conditions $\left(430^{\circ} \mathrm{C}\right.$ for $2 \mathrm{~h}$, max. 20 bar). For sake of comparison, we prepared two additional samples: a composite of SiNWs grown on carbon black (CBSiNW), and a hand-mixed Gt with SiNWs prepared as described in our previous work ${ }^{29}$ (Gt-mix-SiNW). All the samples have the same Si wt\% for proper comparison.

SEM images of Gt-SiNW reveal the formation of long and homogeneous SiNWs with $12 \mathrm{~nm}$ diameter covering completely the graphite flakes (Fig. $1 \mathrm{~d}$-e). The chemical analysis of CHNS elements confirms the weight composition of $\mathrm{Si}$ at $32 \mathrm{wt} \%$ (Table S1). The specific surface area of Gt-SiNW measured by the BET method $\left(56 \mathrm{~m}^{2} / \mathrm{g}\right)$ is in agreement with this $\mathrm{wt} \%$ of $\mathrm{Si}$, taking into account a specific surface area of $230 \mathrm{~m}^{2} / \mathrm{g}$ for pristine SiNWs ${ }^{29}$ SiNWs form a thick "carpet", tightly connected to the graphite surface, thus providing the required electrical conduction pathway from graphite to Si throughout cycling: The crystalline Si core (X-ray diffractogram in Fig. S4, TEM images in Fig. 1f-g and STEM images in Fig. S5) is surrounded by a thin organic monolayer of phenyls as demonstrated in our previous work. ${ }^{29}$ This native layer acts as a protection against the native Si oxidation in air as seen in XPS spectra of Gt-SiNW. A very low oxidation of Si is noticed (Fig. 1b) at $103 \mathrm{eV}$, unlike other Si-Gt composites, ${ }^{12,21,22}$ the doublet at $99.2 \mathrm{eV}$ corresponding to elemental $\mathrm{Si}\left(\mathrm{Si}^{0}\right)$. From the XPS atomic composition $\mathrm{Si} / \mathrm{C} / \mathrm{O} / \mathrm{Au}=66 / 29 / 4.4 / 0.8$, the $\mathrm{O}$ content is accordingly very low. The C1s spectrum (Fig. 1c) shows no $\mathrm{C}-\mathrm{O}$ related peak but only the expected aromatic $\mathrm{C}$ peak at $284.6 \mathrm{eV}$ and a small peak at $282.6 \mathrm{eV}$ related to C-Si from the phenyl-Si bond.

The present SiNW composite synthesis appeared especially well adapted for the development of battery materials. The simple process was easily scaled up, proved highly reproducible and could be adapted to the growth of SiNW composites of chosen Si content on a variety of carbon-based substrates, in particular CB-SiNW used here as a control.

\section{Electrochemical performance of the Gt-SiNW anode in half-cell configuration}

The as-synthesized material Gt-SiNW was process into electrode (80/10/10) following the standard procedure described in the methods section. All the capacity values shown in this paper are based on the total mass of the electrode, unless otherwise stated (theoretical capacities and electrochemical test details in Tables S2 and S3).

The cyclic voltammetry curves of Gt-SiNW anode are shown in Fig. 2a. In the first cathodic scan, peaks observed below $0.1 \mathrm{~V}$ correspond to the lithiation of crystalline $\mathrm{Si}$ and graphite, while peaks observed around $0.2 \mathrm{~V}$ and $0.5 \mathrm{~V}$ correspond to the delithiation of $\mathrm{Li}_{x} \mathrm{C}_{6}$ and $\mathrm{Li}-\mathrm{Si}$ alloy in the anodic scan, respectively. From the second cycle, alloying of amorphous $\mathrm{Si}$ and Li produces a cathodic peak at $0.16 \mathrm{~V}$ and graphite lithiation induces a sharp second peak at $0.05 \mathrm{~V}$. The anodic peak at $0.2 \mathrm{~V}$ is due to graphite delithiation, while dealloying of lithiated amorphous Si occurs at 0.3 and $0.5 \mathrm{~V} .{ }^{3,12}$ The current increases and then stabilizes after 10 cycles (the curve at 20 cycles is superimposed with the curve at 10 cycles), showing the high reversibility of the Gt-SiNW anode.

Fig. $2 \mathrm{~b}$ exhibits the charge discharge profiles of Gt-SiNW anode between 0.01-1.0 $\mathrm{V}$ in lithium halfcells during galvanostatic/potentiostatic cycling. During the first activation step at $\mathrm{C} / 20$, we notice some SEl formation from open-circuit voltage till $0.2 \mathrm{~V}$ followed by a long potential plateau at ca. $0.1 \mathrm{~V}$ 

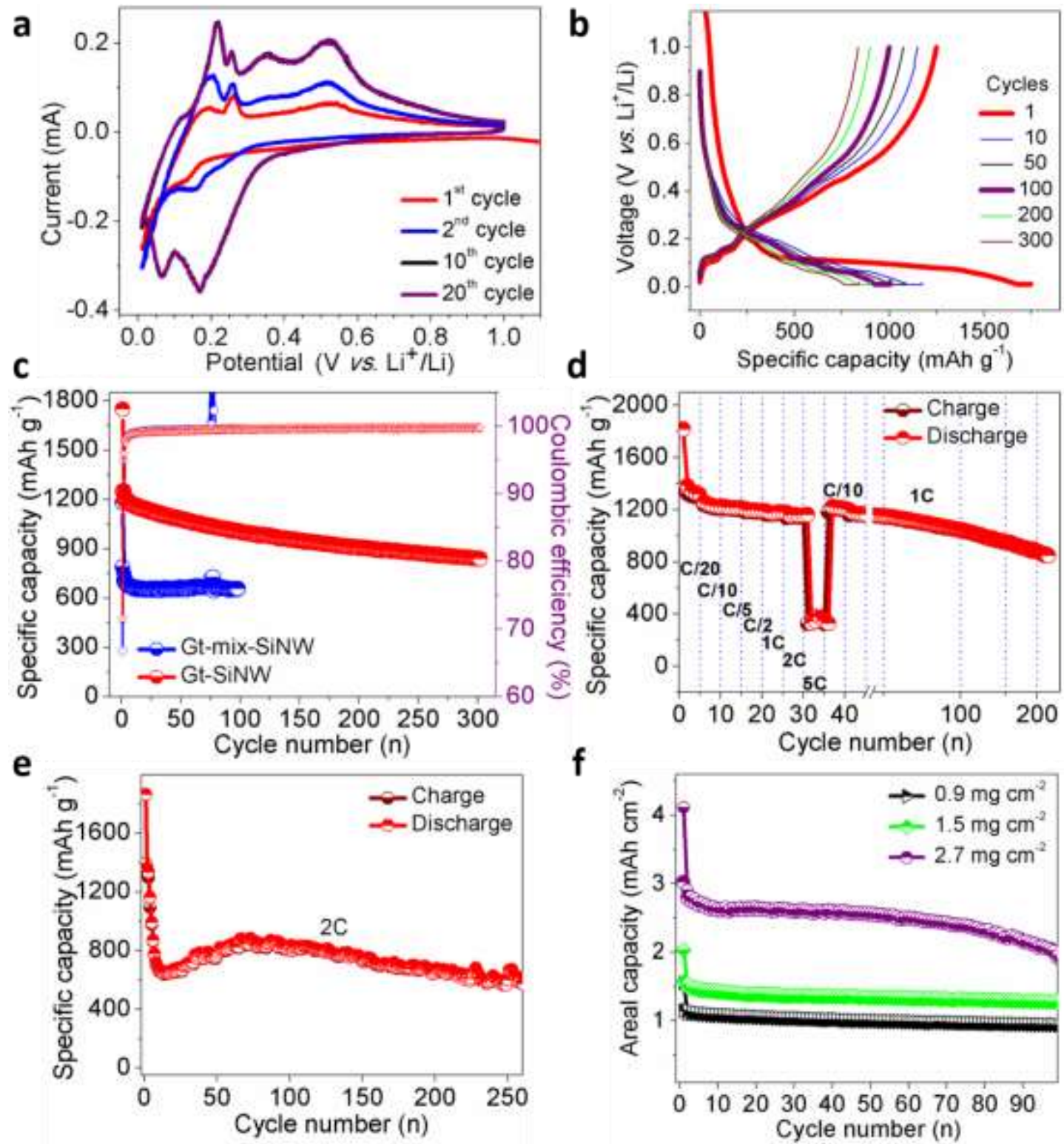

Figure 2. Electrochemical performance of Gt-SiNW anode tested in half-cell configuration vs. Li metal. (a) cyclic voltammograms of Gt-SiNW anode recorded between 0.1 and $1.0 \mathrm{~V}$ versus $\mathrm{Li}^{+} / \mathrm{Li}$ at a scan rate of $0.01 \mathrm{mV} \mathrm{s}^{-1}$. (b) Chargedischarge profile of Gt-SiNW cycled at $0.2 \mathrm{C}$ rate at room temperature in the 0.01-1.0 V vs Li+/Li potential window and with $1 \mathrm{M} \mathrm{LiPF}_{6}$ electrolyte in 1:1 (v/v ethylene carbonate $(E C)$ and diethylene carbonate (DEC) with 2 wt\% of vinylenecarbonate (VC) and 10 wt\% of fluoroethylene carbonate (FEC). (c) Reversible charge/discharge capacity versus cycle number with corresponding Coulombic efficiency of Gt-SiNW and Gt-mix-SiNW at 0.2 C rate (RT, LP30). (d) Rate capability behavior of Gt-SiNW under increasing rates from 0.05 to $5 \mathrm{C}$ (charge/discharge profiles provided in Fig. S8). (e) Extended cyclability of Gt-SiNW at 2 C rate after three activation cycles at C/20, C/10 and C/5 (Coulombic efficiency in Fig. S9). (f) Areal capacity versus cycle number of Gt-SiNW with mass loadings $0.9,1.5$ and $2.7 \mathrm{mg} \mathrm{cm}^{-2}$ at $0.2 \mathrm{C}$ rate.

attributed to the $\mathrm{Li}_{\mathrm{x}} \mathrm{Si}_{\mathrm{y}}$ alloys formation. The material exhibits a discharge and charge capacity of 1747 and $1249 \mathrm{mAh} \mathrm{g}^{-1}$, respectively. The corresponding initial Coulombic efficiency (ICE) of $72 \%$ is the highest reported so far for anodes of similar Si content (Table S4). After the first cycle, the ICE increases quickly above $95.9 \%$ and reaches $99.1 \%$ at cycle 10 . The Gt-SiNW anode exhibits a capacity retention of $80 \%$ (from its $10^{\text {th }}$ cycle capacity) at $0.2 \mathrm{C}$ after 200 cycles with $99.7 \%$ CE (Fig. 2C). The very small shifts in the charge discharge profiles (normalized profiles in Fig. S6) indicate an excellent stable cycling and a very low polarization of the electrode. 
In comparison, the Gt-mix-SiNW at the same loading exhibits a much lower ICE of 57\%, and its reversible specific capacity of $600 \mathrm{mAh} \mathrm{g}^{-1}$ (Fig. 2c) is far lower than the targeted capacity of $1038 \mathrm{mAh}$ $\mathrm{g}^{-1}$ expected from the wt\% of active materials, suggesting that the complete lithiation of SiNWs is not achieved. In addition, we calculated the specific capacity delivered during the end-of-charge potentiostatic phase for the two anodes. This final potentiostatic capacity attains $27 \%$ of the total capacity of Gt-mix-SiNW anodes (Fig. S7) and does not fall under 15\% upon cycling, indicating a strong lack of conductivity in the electrode. As a contrary, the potentiostatic capacity stays in the range between 5 to $8 \%$ for Gt-SiNW anodes all along the 300 cycles. Therefore, the uniform distribution of SiNWs provided by our synthesis approach appears as a key feature that maintains a high internal conductivity in the electrode and extract almost $100 \%$ of the SiNWs capacity.

To evaluate the rate performance, Gt-SiNW anodes were tested at different current rates (C-rate) ranging from $\mathrm{C} / 20$ to $5 \mathrm{C}$ (Fig. 2d). Gt-SiNW anodes demonstrate an excellent rate capability behavior with good capacity retention: the observed reversible delithiation capacity is $1290,1208,1201,1178$, 1168, 1145 and $327 \mathrm{mAh} \mathrm{g}^{-1}$ at current rates of $\mathrm{C} / 20, \mathrm{C} / 10, \mathrm{C} / 5, \mathrm{C} / 2,1 \mathrm{C}, 2 \mathrm{C}$ and $5 \mathrm{C}$, respectively. Notably, the final potentiostatic capacity only accounts for $17 \%$ even at high current rate $(2 \mathrm{C})$, indicating good stability. When the C-rate returns to $0.1 \mathrm{C}$, the Gt-SiNW anode shows an outstanding capacity retention of $99 \%$ and a superimposed charge discharge profile (Fig. S10), indicating an excellent cycling stability. Further, after testing at high charge/discharge rates, the cell still delivers a reversible capacity of $878 \mathrm{mAh} \mathrm{g}^{-1}$ with a capacity retention of $75 \%$ (with respect to $1 \mathrm{C}$ rate) up to 225 cycles at $1 \mathrm{C}$ rate. This steady state cyclability is maintained even at the high C-rate of $2 \mathrm{C}$ (Fig. 2e). After the activation cycles, the Gt-SiNW anode displays a stable reversible capacity of $644 \mathrm{mAh} \mathrm{g}^{-1}$ ( $98 \%$ capacity retention) with an average CE of $99.2 \%$ after 200 cycles.

Several literature reports target both high capacity and stable cycling behavior at high C-rates with a Si-Gt composite. The composites mainly fall in two categories: i) Si deposited on Gt, and ii) mixtures of Si and Gt. Si-deposited-on-Gt systems ${ }^{5,14,17,21}$ (i) have the general advantage of retaining the capacity over hundreds of cycles. However, the Si content is usually limited well below the $32 \mathrm{wt} \%$ achieved here in Gt-SiNW. For example, an increase in Si content from 6 to 9 wt\% results in a sharp capacity decay in Si-nanolayer-embedded graphite. ${ }^{17}$ The observed capacity is thus correspondingly low, ${ }^{17,21}$ usually around $500 \mathrm{mAh} \mathrm{g}^{-1} .20 \mathrm{wt} \%$ of Si in a composite of SiNWs grown in etched graphite ${ }^{14}$ is the highest reported value of Si content in this category, but for a capacity of only $670 \mathrm{mAh} \mathrm{g}^{-1}$ at $0.5 \mathrm{C}$ rate. Alternatively, mixing Si and Gt (ii) makes it easy to increase the Si content up to $50 \%$. However, a common difficulty with this strategy $y^{3,22-27}$ is the irreversible capacity loss ${ }^{24-26}$ as high as $50 \%$ and the swift capacity decay with increasing C-rate: e.g. S. Kim et al. ${ }^{25}$ reported a capacity of only 700/450 mAh $\mathrm{g}^{-1}$ at $0.5 / 2 \mathrm{C}$ rate respectively even with $50 \mathrm{wt} \% \mathrm{Si}$ in Si-Gt composite. Varying Si content from 5 to 50 wt\% in Si-Gt composite, Parekh et al. ${ }^{26}$ found an optimum at $30 \mathrm{wt} \%$ of $\mathrm{Si}$, which is very close to the present optimal $32 \mathrm{wt} \% \mathrm{Si}$ in Gt-SiNW. Nevertheless, the reported capacity is limited to $450 \mathrm{mAh} \mathrm{g}^{-1}$ after 100 cycles at $0.5 \mathrm{C}$ rate, a value far below the capacity of our Gt-SiNW even at $2 \mathrm{C}$ rate. Additionally, S. Zhu et al. ${ }^{3}$ varied the Si content from 5 to $15 \mathrm{wt} \%$ and reported a steady state behavior only for $5 \mathrm{wt} \% \mathrm{Si}$. Increasing Si content to $15 \mathrm{wt} \%$ results in a fast capacity fading. In summary, the GtSiNW capacity of $1200 \mathrm{mAh} \mathrm{g}^{-1}$ achieved here is the best-reported value in a Si-rich composite anode, both at low and high C-rates (Table S4) to the best of our knowledge.

Finally, in order to qualify Gt-SiNW anode for practical applications, the influence of areal capacity was also investigated up to a mass loading of $2.7 \mathrm{mg} \mathrm{cm}^{-2}$ (Fig. 2f). In general, increasing the active material 
mass loading deteriorates the electrochemical behavior due to increased serial resistance related to particle-electrolyte interface and electrode-level disintegration. ${ }^{12}$ Here, Gt-SiNW mass loadings of 0.9 , 1.5 , and $2.7 \mathrm{mg} \mathrm{cm}^{-2}$ deliver areal capacities of $0.94,1.28$, and $3.0 \mathrm{mAh} \mathrm{cm}^{-2}$ at 70 cycles and $0.2 \mathrm{C}$ rate, respectively. This corresponds to almost the same reversible capacity of $1000 \mathrm{mAh} \mathrm{g}^{-1}$ (Fig. S11). The linear increase in areal capacity with mass loading thus indicates that SiNWs and graphite lithiate completely even at higher loading.

\section{Effect of ageing through post-mortem analysis: Electrode swelling (SEM) and morphological modifications over prolonged cycles (FIB-SEM)}

Thickness changes in LIB electrodes is a strong issue for any industrial application. We thus examined the thickness and morphology evolution of Gt-SiNW electrodes before and after cycling with standard
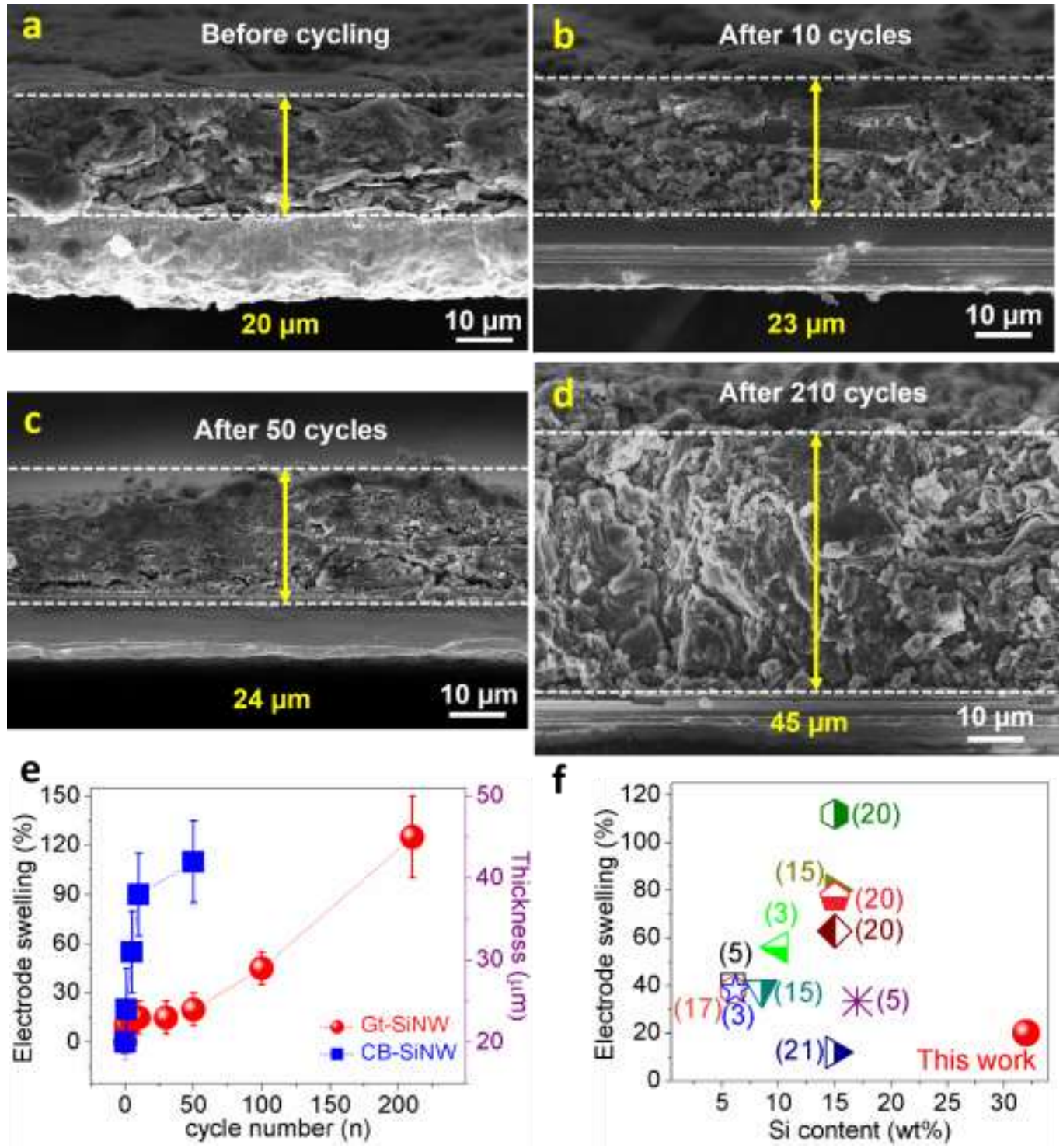

Figure 3. Thickness of cycled Gt-SiNW electrodes by SEM. Cross sectional SEM view of Gt-SiNW electrodes (a) before cycling, and after 10 (b), 50 (c) and 210 (d) cycles at 0.2 C rate. (e) Thickness and swelling percentage of electrodes versus cycle number for Gt-SiNW (spheres) and CB-SiNW (squares). (f) Comparison of reported electrode swelling percentage after 50 cycles versus Si content (wt\%) in the recent literature with the present study. 


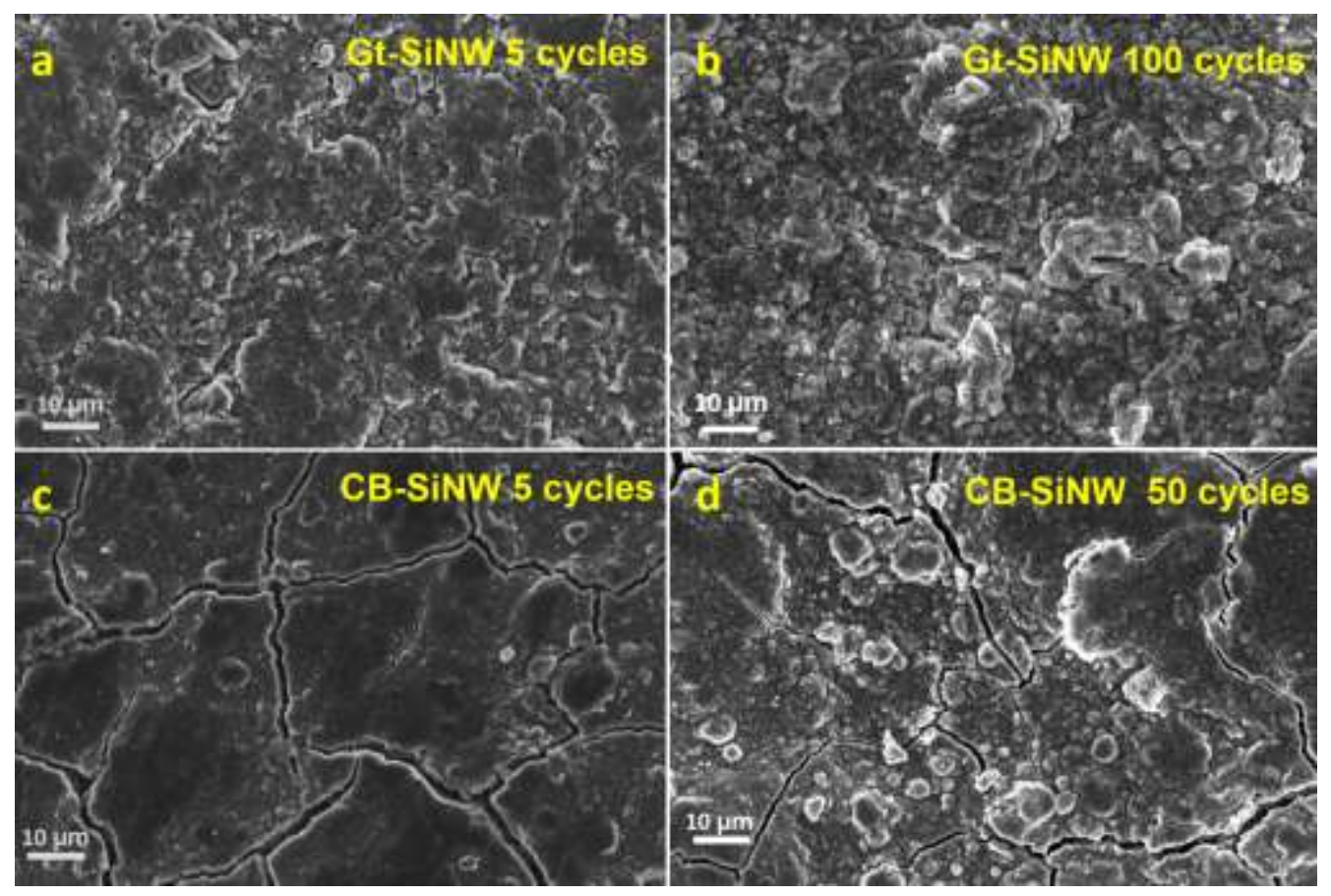

Figure 4. Top view SEM images of cycled electrodes: ( $a$ and b) Gt-SiNW electrodes after 5 ( $a$ ) and 100 (b) cycles at 0.2 C rate. (C and d) Control CB-SiNW electrodes after 5 (c) and 50 (d) cycles.

protocol by SEM in cross-sectional (Fig. 3) and plane view (Fig. 4). The electrodes cycled at $0.5 \mathrm{C}$ at room temperature show acceptable increase in thickness and no significant morphology changes from the first to the $50^{\text {th }}$ cycle (Fig. 3). The electrode swelling of $20 \%$ at 50 cycles is lower than reported for other Si-Gt electrodes, even with lower Si contents (Fig. 3c and f). The Gt-SiNW electrode exhibits 50\% swelling after 100 cycles, a value still within the commercially acceptable limit, ${ }^{5}$ and no obvious damage, crack or delamination appears at the electrode surface (Fig. 4b). For comparison, the control CB-SiNW electrode cycled in the same conditions (Fig. 3e, cycling behavior in Fig. S12) undergoes a huge thickness increase of $55 \%$ as soon as the $5^{\text {th }}$ cycle, accompanied by the formation of severe surface cracks (Fig. 4c and Fig. S13). After 50 cycles (110\%), cracks extend (Fig. 4d) and the electrode material peels off from the current collector, especially after 100 cycles (Fig. S14).

We performed FIB-SEM analysis of Gt-SiNW electrodes at various stages to get a clear understanding of the morphology evolution upon cycling. Fig. 5a-c shows the cross-sectional FIB-SEM images of a pristine Gt-SiNW electrode. Graphite flakes (5-30 $\mu \mathrm{m}$ wide, 0.3-2 $\mu \mathrm{m}$ thick) appear mostly parallel to the current collector, and SiNWs appear as lighter grey in two different forms: SiNW forests embedded in the accessible porosity of graphite or between the graphite flakes (Fig. 5b), and ball-shaped agglomerates (Fig. 5c) containing uniformly distributed nanopores (a few tens of $\mathrm{nm}$ ). The structure is strikingly packed and uniform across the electrode. Most SiNWs cover homogeneously all Gt flakes as a soft, continuous carpet allowing for dense packing. Thus, very few voids are visible as compared to other reported Si-Gt anodes. ${ }^{30,31}$

Noticeable changes are seen after the $1^{\text {st }}$ lithiation (Fig. $5 d-f$ ): especially, the contrast between SiNWs and graphite lowers due to the fact that both materials actively participate in the lithiation process..$^{30,32}$ 
The internal pores are largely filled with a greyish phase (Fig. 5e), suggesting the formation of $\mathrm{Li}_{x} \mathrm{Si}_{y}$ and SEI layer (due to decomposition of electrolyte). After delithiation (Fig. $5 \mathrm{~g}-\mathrm{i}$ ), the porosity within the graphite particles is partly recovered and more pores are visible, but nanopores in the SiNW agglomerates are not recovered. In the $30^{\text {th }}$-cycled electrode upon lithiation (Fig. 5 j-I), SiNW

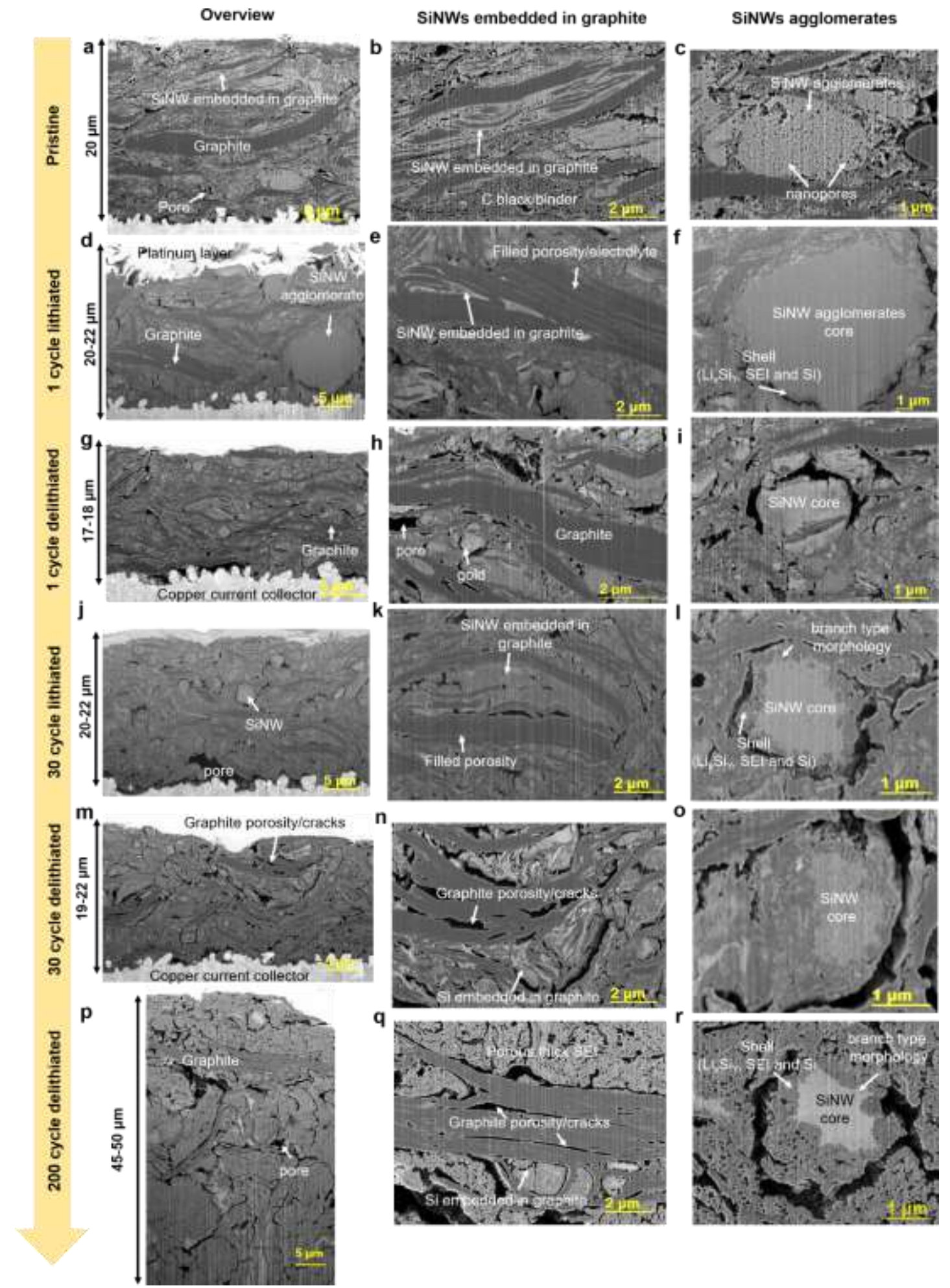

Figure 5. Morphological evolution upon cycling by cross-sectional FIB-SEM of Gt-SiNW electrodes: in pristine state (a), after 1 cycle lithiated (d) and delithiated ( $g$ ), 30 cycles lithiated (j) and delithiated $(\mathrm{m})$ and 200 cycles $(p)$ in delithiated stage at $0.2 \mathrm{C}$ rate. Corresponding high-resolution images of SiNWs embedded in graphite $(b, e$, $h, k, n$ and $q)$, and of SiNWs agglomerates (c, $f, i, l, o$ and $r$ ) upon cycling. 
agglomerates show a branch-type morphology as observed in other Si-Gt composites. ${ }^{31}$ The core of the agglomerates shrinks as the layer around agglomerates, probably composed of $\mathrm{Li}_{x} \mathrm{Si}_{y}$ and $\mathrm{SEI}$, gets thicker ${ }^{31}$ (EDX mapping in Fig. S15 and S16). Bigger fractures appear in graphite flakes (Fig. 5m-o) upon delithiation. As expected from the layered structure of graphite, the cracks extend in the plane direction parallel to the flakes, and thus to the current collector. ${ }^{33,34}$ The ageing effects are more pronounced at 200 cycles (Fig. 5p-r): the electrode shows more voids around the graphite flakes and a thicker shell is grown around SiNW agglomerates, by consuming part of the agglomerates (Fig. 5r). Nevertheless, a distinct Si core is still visible in the SiNW agglomerates in the delithiated state even at 200 cycles.

From SEM and FIB-SEM analysis, we thus get a global insight into i) macroscopic electrode swelling, and ii) microscopic changes occurring during cycling including the changes in tortuosity path. The GtSiNW electrode exhibits only $15 \%$ swelling after 30 cycles, a remarkably low value with such a high $\mathrm{Si}$ content as compared to literature (Fig.3f). Although the electrode is densely packed, it contains very small sized pores in between SiNWs (Fig. 5c), that accommodate part of the Si swelling (Fig. 5f). As for SiNWs embedded in graphite, their swelling upon lithiation applies a constraint orthogonal to the layered structure of graphite. Thanks to the alignment of the graphite flakes parallel to the current collector, this constraint mainly translates in a vertical expanding/shrinking during lithiation/delithiation. This avoids macroscopic cracks as observed in CB-SiNW electrodes (Fig. 4), maintaining electrical contact with the current collector. Indeed, electrochemical impedance spectra of Gt-SiNW anode recorded along cycling indicate a very low charge transfer resistance ( $R_{C T}$ ) (Fig. S17), consistent with the low polarization observed on the charge discharge profiles (Fig. 2b and Fig. S6). $R_{C T}$ stabilizes at $\sim 14 \Omega$ from the $5^{\text {th }}$ to the $200^{\text {th }}$ cycle, indicating good internal connectivity with a stable SEI and preserved mechanical integrity of the electrode throughout cycling. ${ }^{32,35,36}$

The uniform distribution of SiNWs on Gt is key in obtaining a controlled, low swelling of the electrode at all points. We observe that core $\mathrm{Si}$ in the agglomerates is gradually consumed to form a shell that consists of $\mathrm{Li}_{x} \mathrm{Si}_{y}$, $\mathrm{Si}$ and $\mathrm{SEl}$ over cycling, ${ }^{31}$ but the $\mathrm{Si}$ in the shell still participates in the lithiation process as evidenced from the very low capacity decay of Gt-SiNW anode. The thicker shell around SiNW agglomerates thus seems more complex than the standard SEI model reported on graphite and $\mathrm{Si}^{30,31}$ The slowly increasing porosity mainly oriented by the Gt flakes keeps the electrode swelling under control even after 100 cycles. This maintains efficiently the electrode integrity and leads to a steady state cycling behavior.

These results thus show the positive synergy of graphite and SiNWs when tightly bound in insuring the desired electrochemical performance. Our unique Gt-SiNW design efficiently provides i) high capacity, ii) electric network, iii) cushion to accommodate the volume expansion of SiNWs even at high loading, and iv) desired electrode integrity at prolonged cycling.

\section{Prelithiated Gt-SiNW/NMC full cell testing}

The practical application of our electrodes was evaluated in a full-cell configuration with a Gt-SiNW anode and NMC cathode (detailed information on electrochemical cycling in Table S5 and S6). In order to reduce the lithium loss in the irreversible capacity, the anode is prelithiated in a half-cell configuration: the working electrode is lithiated with Li metal electrode up to $0.01 \mathrm{~V}$ at $0.05 \mathrm{C}$ rate 

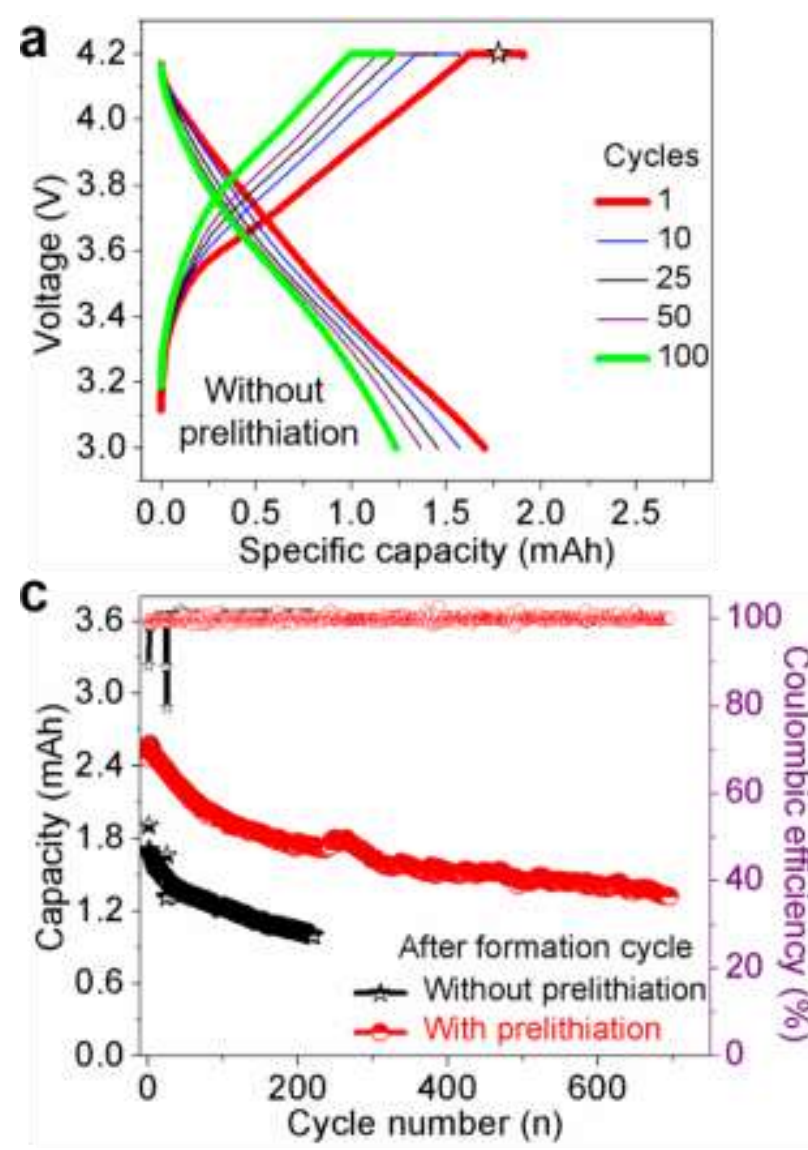
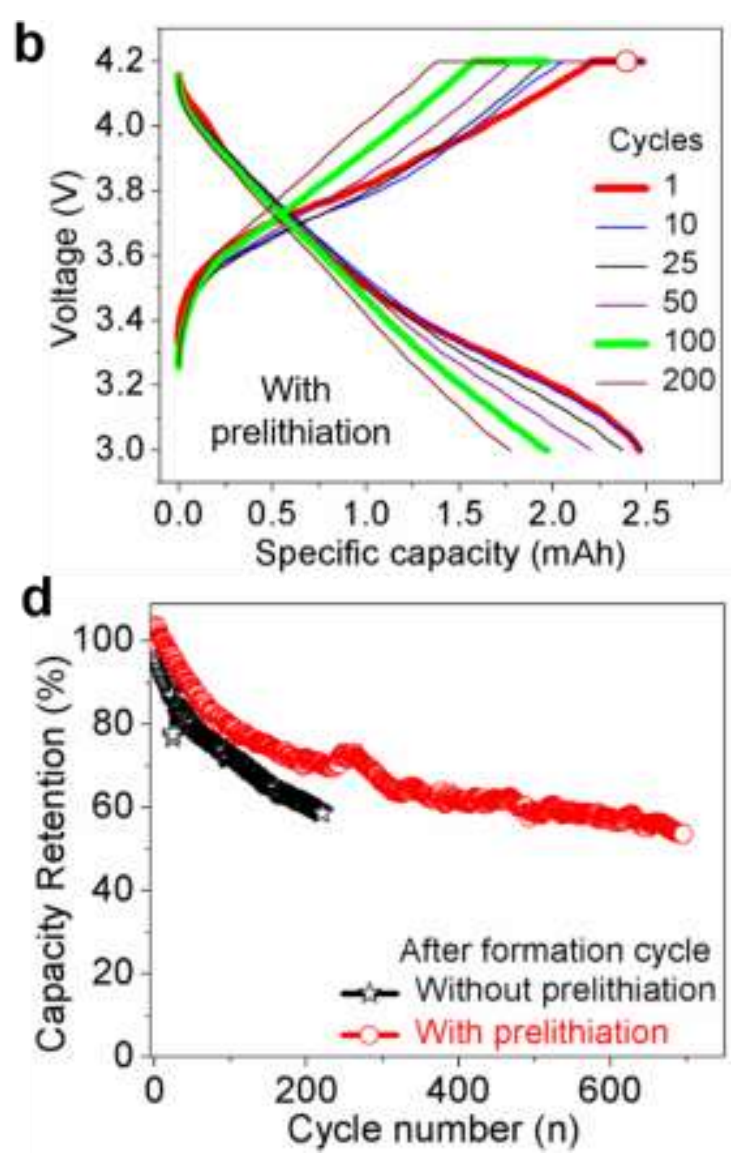

Figure 6. Electrochemical comparison of Gt-SiNW/NMC full cell with and without prelithiation. Charge-discharge profile of full cells without (a) and with (b) prelithiation at $0.5 \mathrm{C}$ rate. Comparison of corresponding reversible capacities, Coulombic efficiency (c) and capacity retention (d) with (circles) and without (stars) prelithiation as a function of cycle number.

(anode balancing and prelithiation detailed in Table S3 and S5), and then coupled with an NMC-622 cathode. Fig. 6 shows the cycling performance of the full cell cycled between 3.0 to $4.2 \mathrm{~V}$ at $\mathrm{C} / 2$ with and without prelithiation. The prelithiated full cell exhibits initial charge and discharge capacity of 3.35 and $2.96 \mathrm{mAh}$ (Fig. S18). The Coulombic efficiency of $88 \%$ in the formation cycle at $0.05 \mathrm{C}$ attains $99.4 \%$ in the first cycle and reaches $99.9 \%$ just after 8 cycles at $0.5 \mathrm{C}$. Then, the full cell displays a reversible capacity of $1.6 \mathrm{mAh}$ even after completing 300 cycles at $0.5 \mathrm{C}$ rate with a capacity retention of $70 \%$ at an average voltage of $3.76 \mathrm{~V}$. The full cycle delivers a high energy density of $414 \mathrm{Wh} \mathrm{kg}^{-1}$ (calculation in Table S6), which compares well with the state-of-the-art. ${ }^{17}$ Notably, the full cell still delivers a capacity of $1.3 \mathrm{mAh}$ after 700 cycles. As expected, the full cell without prelithiation exhibits a much lower energy density (306 $\mathrm{Wh} \mathrm{kg}^{-1}$ ) mainly due to its low ICE (58\%), indicating that prelithiation is necessary at this stage. The good and stable internal connectivity of the Gt-SiNW anode is also visible in the full cell cycling as the full cells show a low polarization (Fig. S19) and a relatively small capacity contribution from the potentiostatic step (16.5-18\%), independent of the cycle number.

\section{Conclusions}

For the first time, we introduce a simple, low cost and scalable synthesis process using mild reagents and medium temperature for growing SiNWs on graphite with a high wt\% of Si (32\%). Our highly reproducible approach offers viability towards commercial application: first, the process is very versatile and reliable, and can stand wide changes in catalyst loading or type of carbon substrates. 
Second, it was easily scaled up without compromising neither the yield nor the structural quality of the nanomaterial. Third, the targeted Si loading, and consequently the specific capacity, is easily adjusted to the battery requirements by fine-tuning the quantities of catalyst and Si precursors. It is well-known that increasing the Si loading in anode materials usually results in poor long-term cycling due to severe electrode swelling and instability. Besides, a high Si content lowers the operating voltage in full cells. Therefore, determining the appropriate ratio of Si and Gt and controlling their distribution are crucial in obtaining the high energy density in viable LIBs. In this aim, our exclusively designed architecture provides the effective ratio of $\mathrm{Si}$ and $\mathrm{Gt}$ and the desired homogeneous distribution of SiNWs (with the native layer protection towards oxidation) on Gt.

Gt-SiNW anodes exhibit an excellent trade-off in electrochemical performance in terms of ICE (72\%), cyclability ( $900 \mathrm{mAh} \mathrm{g}^{-1}$ and $72 \%$ capacity retention at 300 cycles), rate capability ( $1145 \mathrm{mAh} \mathrm{g}^{-1}$ at $2 \mathrm{C}$ rate) and extended cycling at high rate (629 $\mathrm{mAh} \mathrm{g}^{-1}$ after 250 cycles at $2 \mathrm{C}$ rate). It overcomes the technical hurdles associated with the severe volume changes of Si-rich anodes, and exhibits an acceptable electrode swelling of $20 \%$ after 50 cycles. The material is also tunable in formulating electrodes, as Gt-SiNW displays an outstanding stability irrespective of the mass loading ranging from 0.9 to $2.7 \mathrm{mg} \mathrm{cm}^{-2}$. As for Li-ion batteries, a full Gt-SiNW/NMC cell demonstrates an energy density of $414 \mathrm{Wh} \mathrm{kg}^{-1}$ along with a capacity retention of $70 \%$ after 300 cycles. Thus, Gt-SiNW passes the stateof-the-art both in half and full cells in terms of durability at high energy density. Thanks to an in-depth structural analysis by FIB-SEM, we found that graphite plays a key role in attaining the high volumetric energy density offered by SiNWs: it facilitates fast electron transfer, and accommodates and directs the $\mathrm{Si}$ volume changes during cycling, which ensures the long-term mechanical integrity of the electrodes. Improvements are under way in fine-tuning the graphite morphology and the SiNW surface passivation to increase the ICE. Thus, the present work paves the way towards next generation anodes with both high energy density and commercial viability, and it could be a significant breakthrough for electric vehicle or grid energy storage.

\section{Methods}

\section{Materials}

Tetrabutylammonium tetrafluoroborate $\left(\mathrm{TBABF}_{4}\right)$ and carboxymethylcellulose sodium (CMC) were purchased from Sigma Aldrich. Gold tetrachloroauric acid, tetraoctylammonium bromide (TOAB), diphenylsilane and sodium chloride were purchased from Alfa Aesar. Graphite (grade: SLP-30 and specific surface area: $6.5 \mathrm{~m}^{2} / \mathrm{g}$ ) and carbon black Super-P (CB) were purchased from TIMCAL.

\section{AuNP growth}

Following Brust's method ${ }^{37}$ optimized by Hostetler, ${ }^{38}$ gold tetrachloroauric acid $\mathrm{HAuCl}_{4} \cdot 3 \mathrm{H}_{2} \mathrm{O}$ dissolved in water is transferred in toluene using TOAB, then reduced with $\mathrm{NaBH}_{4}$ and stabilized with DDT (DDT/Au molar ratio 2:1), leading to 1.5-2 nm diameter AuNPs quantitatively.

\section{SiNW growth on graphite or carbon black substrate}

SiNWs are grown in a stainless-steel pressure reactor of inner volume $65 \mathrm{~cm}^{3}$ heated by induction (see details in Fig. S3). AuNPs (20 mg) in solution in $5 \mathrm{~mL}$ of hexane/isooctane 10:1 are uniformly deposited on natural graphite powder $(400 \mathrm{mg})$ via solution drying. The AuNP-loaded Gt is sealed with diphenylsilane $(6 \mathrm{~mL})$ in the reactor under vacuum before heating at $430^{\circ} \mathrm{C}$ for $2 \mathrm{~h}$. After cooling down, 
the collected black powder is washed thrice with dichloromethane to remove impurities and dried at $80^{\circ} \mathrm{C}$ to yield Gt-SiNW (620 mg, 32wt\% Si). The control material using carbon black ( $400 \mathrm{mg}$ ) instead of graphite yields CB-SiNW (670 mg, 40\%wtSi). A scaled-up synthesis of Gt-SiNW is obtained in a $130 \mathrm{~cm}^{3}$ stainless steel reactor using the same process $(800 \mathrm{mg}$ graphite, $40 \mathrm{mg}$ AuNPs, $12.5 \mathrm{~mL}$ diphenylsilane, $430^{\circ} \mathrm{C}, 3 \mathrm{~h}$ ), yielding $1.28 \mathrm{~g}$ of Gt-SiNW. Growth of pristine SiNWs was done as previously reported ${ }^{29}$ by using finely ground $\mathrm{NaCl}$ powder as a sacrificial substrate instead of using carbon substrate. $\mathrm{NaCl}$ was removed by washing with water after growth.

\section{Materials characterization}

Phase characterization was performed with powder X-ray diffraction technique on a Brüker D8 advance diffractometer $\theta-2 \theta$ configuration with a $\mathrm{Cu}$ anticathode. The scanning step used was $0.02^{\circ}$ with a counting time of $1.2 \mathrm{~s}$ per step. CHNS elemental analysis was performed using Carbon/Sulfur Analyser-EMIA-320 V from Horiba. The analysis allows to measure carbon content after fast combustion of the sample in inductive furnace (between 1500 and $2000^{\circ} \mathrm{C}$ ) under pure $\mathrm{O}_{2} \cdot \mathrm{CO}_{2}$ and $\mathrm{CO}$ are formed and measured by IR sensors, in triplicates. Scanning Electron microscopy was operated on a Zeiss Ultra 55 microscope at an accelerating voltage of $5 \mathrm{kV}$ and working distance of $5 \mathrm{~mm}$. Scanning transmission electron microscopy was realised on a Cs-corrected FEI Titan STEM operated at 200 kV. X-ray photoelectron spectroscopy was performed on a Versa Probe II spectrometer (ULVAC$\mathrm{PHI})$ equipped with a monochromated Al $\mathrm{K}_{\alpha}$ source $(1486.6 \mathrm{eV})$ with peak alignment on the Au5/2f peak. The Brunauer, Emmet, and Teller (BET) method was used to measure the SBET specific surface of the different samples using a Micromeritic apparatus (Tristar II). Electrochemical studies, including electrochemical impedance spectroscopy, were carried out using Biologic VMP3 multichannel potentiostat and ARBIN charge-discharge cycle life tester. The Nyquist plots were recorded potentiostatically by applying an AC voltage of $10 \mathrm{mV}$ amplitude in the $100 \mathrm{kHz}$ to $10 \mathrm{mHz}$ frequency range. For microscopy analyses, the cells were disassembled in the glove box. The electrodes were rinsed with dimethyl carbonate and dried before analysis.

\section{Electrochemical characterization}

The electrode was fabricated from a mixture containing active material, super $\mathrm{P}$ carbon black (additive) and CMC (binder) diluted in pure distilled water in the weight ratio of 80:10:10 for Gt-SiNW, CB-SiNW and Gt-mix-SiNW, and 50:25:25 for pristine SiNWs. The resultant slurry was coated using doctor blade method on thin copper foil $(12 \mu \mathrm{m})$ and dried at $80^{\circ} \mathrm{C}$ for overnight (mass loading 1.0 $\mathrm{mg} \mathrm{cm}{ }^{-2}$, thickness $20 \mu \mathrm{m}$ ). The Celgard separator was soaked with an electrolyte of $1 \mathrm{M} \mathrm{LiPF}_{6}$ in 1:1 $\mathrm{v} / \mathrm{v}$ ethylene carbonate (EC) and diethylene carbonate (DEC) with $2 \mathrm{wt} \%$ of vinylenecarbonate and 10 $w t \%$ of fluoroethylene carbonate. 2032 coin cells were assembled with lithium metal as reference and counter electrode in an Argon-filled glove box and crimp sealed. Electrochemical properties of the half-cells were evaluated in the potential window between $0.01 \mathrm{~V}$ to $1.0 \mathrm{~V}$. Along the manuscripts all the potentials measured in half cell configuration refer to Li metal counter electrode and are thus expressed as vs. $\mathrm{Li}^{+} / \mathrm{Li}$.

The $\mathrm{Li}\left(\mathrm{Ni}_{0.6} \mathrm{CO}_{0.2} \mathrm{Mn}_{0.2}\right) \mathrm{O}_{2}$ (NMC-622) cathode was kindly provided by VARTA Micro Innovation GmbH and used as received. It was fabricated on a roll-to-roll coating machine using doctor blade technique and contained an active material proportion of $94 \mathrm{wt} \%$ (mass loading $16 \mathrm{mg} \mathrm{cm}^{-2}$, thickness $70 \mu \mathrm{m}$ ). Cathodes were tested in half-cell configuration between 3 to $4.3 \mathrm{~V}$ vs Li+/Li (Fig. S20), with $1 \mathrm{M} \mathrm{LiPF}_{6}$ in $\mathrm{EC} /$ propylene carbonate/dimethyl carbonate $(\mathrm{v} / \mathrm{v} / \mathrm{v} 1: 1: 1)$ as electrolyte and Celgard as the 
separator. The full cells were assembled with Gt-SiNW as anode and NMC-622 as cathode (anode to cathode capacity ratio 1.1:1) with the same electrolyte and separator as for Gt-SiNW half cells. Galvanostatic/potentiostatic charging/discharging was carried out between $3.0 \mathrm{~V}$ and $4.2 \mathrm{~V}$ at $0.5 \mathrm{C}$.

\section{FIB-SEM sample preparation and characterization approach for the aged electrodes}

The disassembled electrodes were transferred through a special transfer holder from the glove box to a Zeiss cross-beam 550 focused ion beam (FIB-SEM) without air exposure. SEM images were acquired using secondary electron (SE) and energy selective backscattered electron (BSE) detectors with a primary beam energy of $1.5 \mathrm{kV}$ and a beam current of $1 \mathrm{nA}$. Details of the sample preparation steps are given in ref $^{31}$. The FIB sectioning was carried out at $30 \mathrm{kV}$ and a low beam current of $690 \mathrm{pA}$. Considering the smaller size of SiNWs (typically $12 \mathrm{~nm}$ ), SEM images were recorded with a pixel size of $5 \mathrm{~nm}$ and a slice depth of $10 \mathrm{~nm}$.

\section{Acknowledgements}

The authors acknowledge the financial support from European Project Flagship Graphene Core 2 under grant agreement no. 785219 and European Union's Horizon 2020 Research and Innovation Program of "Silicon based materials and new processing technologies for improved lithium-ion batteries" (SiNTBAT) under grant agreement no. 685716. S.K. thanks Sylvie Geniès for helping in crosssectional SEM imaging, Nathalie Herlin for the CHNS elemental analysis, Daniel Tomasi for helping in electrode preparation and Christoph Stangl from VARTA Innovation for providing NMC cathodes. P.C. thanks Claire Villevieille for discussion and Laurent Miquet for making the scale-up of SiNW growth safe.

\section{References}

1 R. Schmuch, R. Wagner, G. Hörpel, T. Placke and M. Winter, Nat Energy, 2018, 3, 267-278.

2 M. Armand and J.-M. Tarascon, Nature, 2008, 451, 652-657.

3 S. Zhu, J. Zhou, Y. Guan, W. Cai, Y. Zhao, Y. Zhu, L. Zhu, Y. Zhu and Y. Qian, Small, 2018, 14, 1802457.

4 M. N. Obrovac and V. L. Chevrier, Chem. Rev., 2014, 114, 11444-11502.

5 S.-H. Choi, G. Nam, S. Chae, D. Kim, N. Kim, W. S. Kim, J. Ma, J. Sung, S. M. Han, M. Ko, H.-W. Lee and J. Cho, Adv. Energy Mater., 2019, 9, 1803121.

6 C. K. Chan, H. Peng, G. Liu, K. Mcllwrath, X. F. Zhang, R. A. Huggins and Y. Cui, Nature Nanotechnology, 2008, 3, 31-35.

7 J. Sourice, A. Quinsac, Y. Leconte, O. Sublemontier, W. Porcher, C. Haon, A. Bordes, E. De Vito, A. Boulineau, S. Jouanneau Si Larbi, N. Herlin-Boime and C. Reynaud, ACS applied materials \& interfaces, 2015, 7, 6637-44.

8 J. Saint, M. Morcrette, D. Larcher, L. Laffont, S. Beattie, J.-P. Pérès, D. Talaga, M. Couzi and J.M. Tarascon, Advanced Functional Materials, 2007, 17, 1765-1774.

9 H. Wu, G. Chan, J. W. Choi, I. Ryu, Y. Yao, M. T. McDowell, S. W. Lee, A. Jackson, Y. Yang, L. Hu and Y. Cui, Nature Nanotech, 2012, 7, 310-315.

10 H. Jia, P. Gao, J. Yang, J. Wang, Y. Nuli and Z. Yang, Adv. Energy Mater., 2011, 1, 1036-1039.

11 X. Li, M. Gu, S. Hu, R. Kennard, P. Yan, X. Chen, C. Wang, M. J. Sailor, J.-G. Zhang and J. Liu, Nat Commun, 2014, 5, 4105. 
12 W. An, B. Gao, S. Mei, B. Xiang, J. Fu, L. Wang, Q. Zhang, P. K. Chu and K. Huo, Nat Commun, 2019, 10, 1447.

13 G. Jeong, J.-G. Kim, M.-S. Park, M. Seo, S. M. Hwang, Y. U. Kim, Y.-J. Kim, J. H. Kim and S. X. Dou, Acs Nano, 2014, 8, 2977.

14 S. Jeong, J.-P. Lee, M. Ko, G. Kim, S. Park and J. Cho, Nano Lett., 2013, 13, 3403-3407.

15 S. Chae, S.-H. Choi, N. Kim, J. Sung and J. Cho, Angew. Chem. Int. Ed., 2020, 59, 110-135.

16 D. Lin, Z. Lu, P.-C. Hsu, H. R. Lee, N. Liu, J. Zhao, H. Wang, C. Liu and Y. Cui, Energy Environ. Sci., 2015, 8, 2371-2376.

17 M. Ko, S. Chae, J. Ma, N. Kim, H.-W. Lee, Y. Cui and J. Cho, Nat Energy, 2016, 1, 16113.

18 X. Li, P. Yan, X. Xiao, J. H. Woo, C. Wang, J. Liu and J.-G. Zhang, Energy Environ. Sci., 2017, 10, 1427-1434.

19 S. Chae, M. Ko, S. Park, N. Kim, J. Ma and J. Cho, Energy Environ. Sci., 2016, 9, 1251-1257.

20 S. Jiang, B. Hu, Z. Shi, W. Chen, Z. Zhang and L. Zhang, Advanced Functional Materials, 2020, 30, 1908558.

21 N. Kim, S. Chae, J. Ma, M. Ko and J. Cho, Nat Commun, 2017, 8, 812.

22 S. Y. Kim, J. Lee, B.-H. Kim, Y.-J. Kim, K. S. Yang and M.-S. Park, ACS Appl. Mater. Interfaces, 2016, 8, 12109-12117.

23 Q. Xu, J.-Y. Li, J.-K. Sun, Y.-X. Yin, L.-J. Wan and Y.-G. Guo, Adv. Energy Mater., 2017, 7, 1601481.

24 H. Su, A. A. Barragan, L. Geng, D. Long, L. Ling, K. N. Bozhilov, L. Mangolini and J. Guo, Angewandte Chemie International Edition, 2017, 56, 10780-10785.

25 S. Kim, Y. K. Jeong, Y. Wang, H. Lee and J. W. Choi, Adv. Mater., 2018, 30, 1707594.

26 M. H. Parekh, A. D. Sediako, A. Naseri, M. J. Thomson and V. G. Pol, Advanced Energy Materials, 2020, 10, 1902799.

27 P. Li, J.-Y. Hwang and Y.-K. Sun, ACS Nano, 2019, 13, 2624-2633.

28 J. K. Lee, C. Oh, N. Kim, J.-Y. Hwang and Y.-K. Sun, J. Mater. Chem. A, 2016, 4, 5366-5384.

29 O. Burchak, C. Keller, G. Lapertot, M. Salaün, J. Danet, Y. Chen, N. Bendiab, B. Pépin-Donat, C. Lombard, J. Faure-Vincent, A. Vignon, D. Aradilla, P. Reiss and P. Chenevier, Nanoscale, 2019, 11, 22504-22514.

30 C. L. Berhaut, D. Z. Dominguez, P. Kumar, P.-H. Jouneau, W. Porcher, D. Aradilla, S. Tardif, S. Pouget and S. Lyonnard, ACS Nano, 2019, 13, 11538-11551.

31 P. Kumar, D. Z. Dominguez, S. Tardif, S. Pouget and P.-H. Jouneau, Small, 2020, 1906812.

32 R. Ruffo, S. S. Hong, C. K. Chan, R. A. Huggins and Y. Cui, Journal of Physical Chemistry C, 2009, 113, 11390-11398.

33 J. Ma, J. Sung, J. Hong, S. Chae, N. Kim, S.-H. Choi, G. Nam, Y. Son, S. Y. Kim, M. Ko and J. Cho, Nat Commun, 2019, 10, 475.

34 N. Lin, Z. Jia, Z. Wang, H. Zhao, G. Ai, X. Song, Y. Bai, V. Battaglia, C. Sun, J. Qiao, K. Wu and G. Liu, Journal of Power Sources, 2017, 365, 235-239.

35 M. Ratynski, B. Hamankiewiecz, M. Krajewski, M. Boczar, D. A. Buchberger and A. Czerwinski, Electrocatalysis, 2020, 11, 160-169.

36 E. Radvanyi, W. Porcher, E. De Vito, A. Montani, S. Franger and S. Jouanneau Si Larbi, Phys. Chem. Chem. Phys., 2014, 16, 17142-17153.

37 M. Brust, Walker M, D. Bethell, D. J. Schiffrin and R. Whyman, J Chem Soc, Chem Comm, 1994, 801-802. 
38 M. J. Hostetler, J. E. Wingate, C.-J. Zhong, J. E. Harris, R. W. Vachet, M. R. Clark, J. D. Londono, S. J. Green, J. J. Stokes, G. D. Wignall, G. L. Glish, M. D. Porter, N. D. Evans and R. W. Murray, Langmuir, $1998,14,17-30$.

SUPPLEMENTARY INFORMATION

\section{High silicon loading for high energy lithium batteries with an easy scalable silicon nanowires-grown-on-graphite composite}

Saravanan Karuppiah ${ }^{\mathrm{a}, \mathrm{b}}$, Caroline Keller ${ }^{\mathrm{a}, \mathrm{b}}$, Praveen Kumar ${ }^{\mathrm{c}}$, Pierre-Henri Jouneau ${ }^{\mathrm{c}}$, Dmitry Aldakov $^{\mathrm{a}}$, Jean-Baptiste Ducros ${ }^{\mathrm{b}}$, Gérard Lapertot ${ }^{\mathrm{d}}$, Pascale Chenevier*a and Cédric Haon*b

${ }^{a}$ Univ. Grenoble Alpes, CEA, CNRS, IRIG, SYMMES, STEP, 38000 Grenoble, France

${ }^{\mathrm{b}}$ Univ. Grenoble Alpes, CEA, LITEN, DEHT, 38000 Grenoble, France

${ }^{c}$ Univ. Grenoble Alpes, CEA, IRIG, MEM, LEMMA, 38000 Grenoble, France

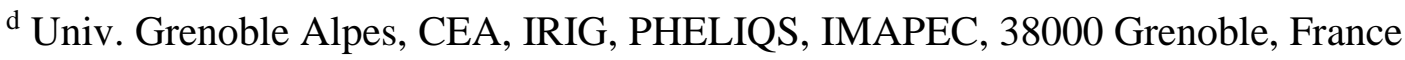

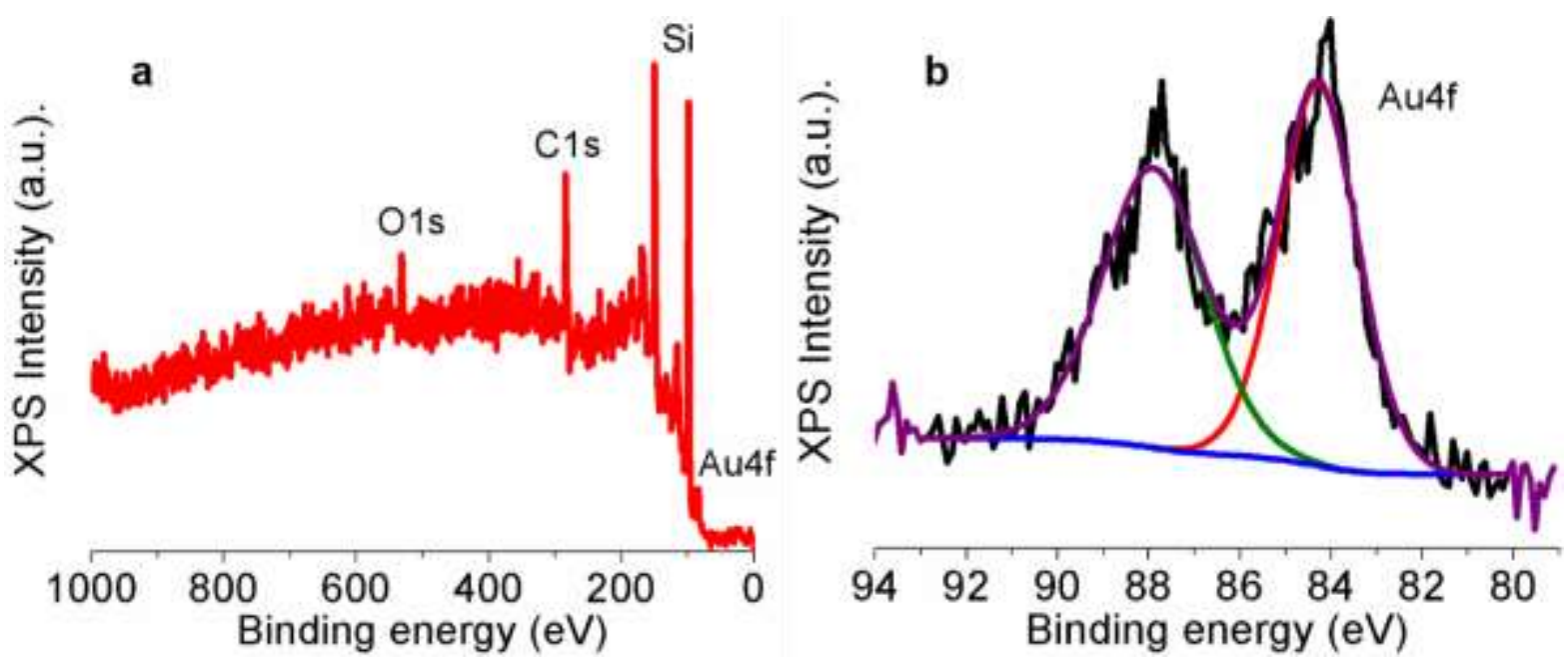

Figure S1. XPS Spectra (a) survey and (b) deconvoluted spectra of Au4f orbitals of Gt-SiNW. 


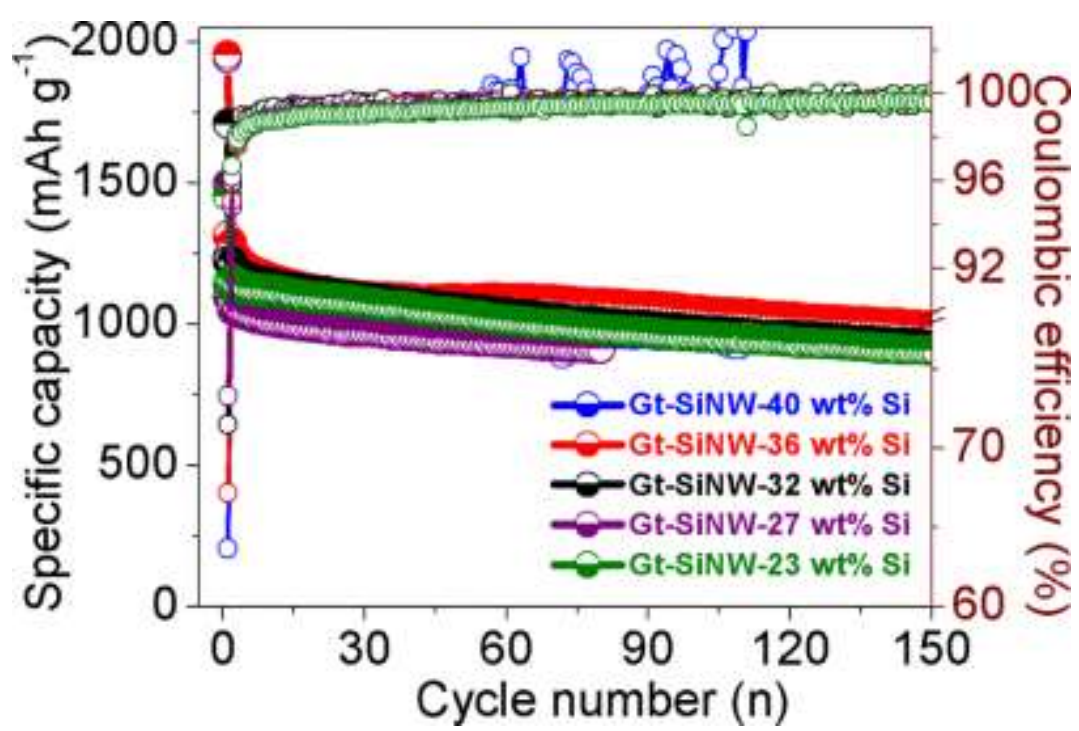

Figure S2. Electrochemical performance of several samples of Gt-SiNW with different Si wt\% from 23 to 40 cycled at room temperature in half-cell configuration at $0.2 \mathrm{C}$ rate using $1 \mathrm{M}$ $\mathrm{LiPF}_{6}$ in 1:1 (v/v) EC: DEC with $2 \mathrm{wt} \% \mathrm{VC}$ and $10 \mathrm{wt} \%$ FEC as electrolyte.

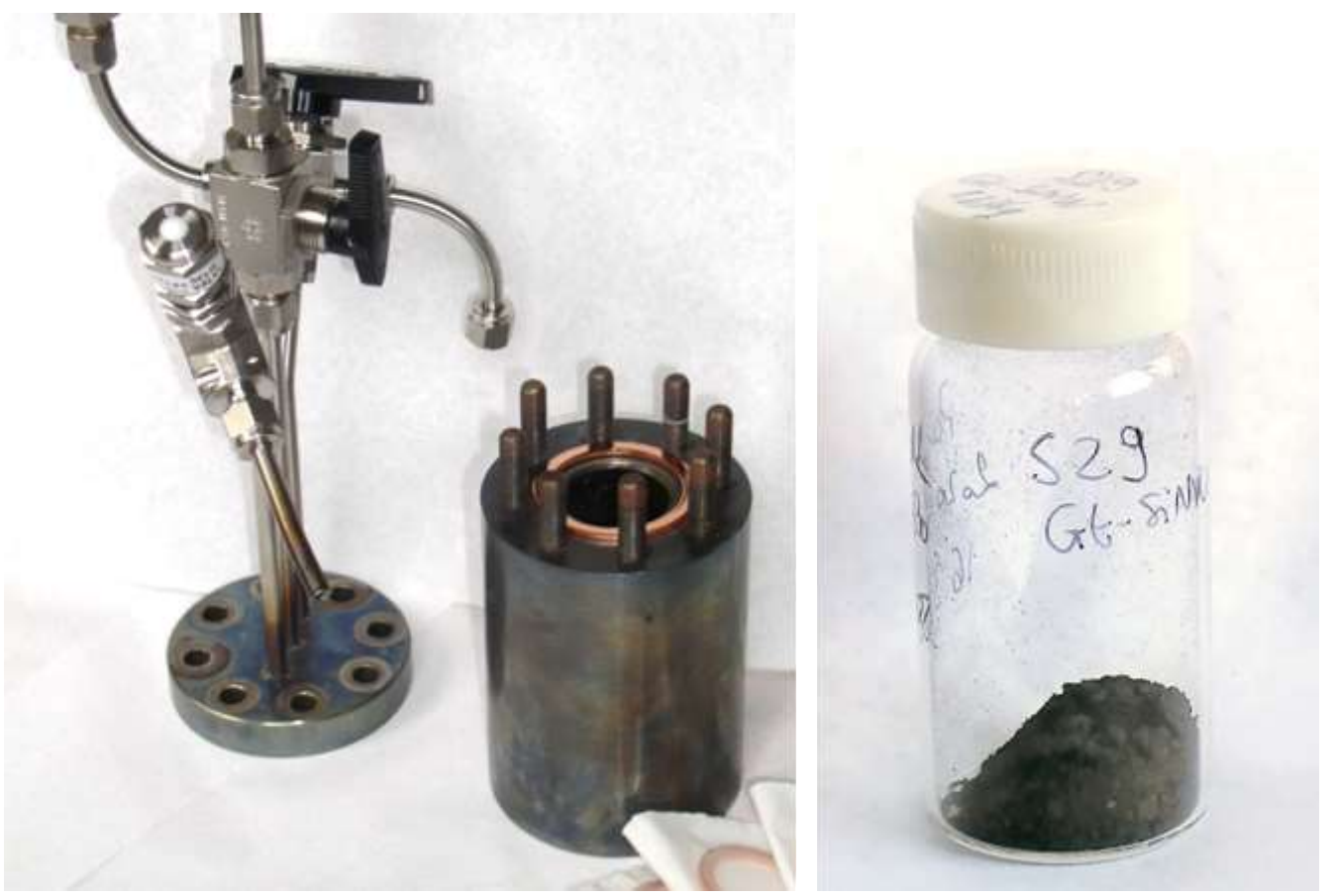


Figure S3. Photograph of the stainless steel SiNW growth reactor (left), and of the Gt-SiNW product $\left(1.28 \mathrm{~g}\right.$ in a $20 \mathrm{~mL}$ vial). Inner chamber: diameter $3 \mathrm{~cm}$, height $9.2 \mathrm{~cm}\left(65 \mathrm{~cm}^{3}\right)$. Outer dimensions: diameter $8 \mathrm{~cm}$, height $10.3 \mathrm{~cm}$. Three stainless steel tubes (inner diameter $4 \mathrm{~mm}$, outer diameter $6 \mathrm{~mm}$ ) soldered in the lid connect a pressure safety valve, a pressure sensor and a vacuum valve. Tightness is insured by pressing a standard copper vacuum ring. The reactor is heated by induction in a 7-turn coil connected to a high frequency generator $(34 \mathrm{kHz}, 2.0 \mathrm{kV}$, 4.0 A), until the inner pressure attains 20 bar. The scale-up reactor is identical except that the inner chamber is $18.4 \mathrm{~cm}$ deep.

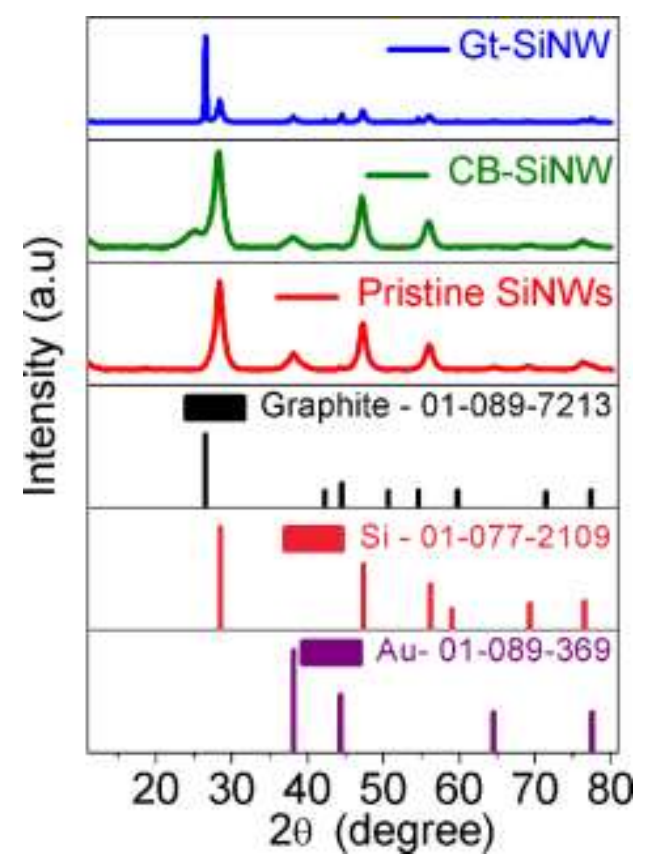

Figure S4. XRD pattern of pristine SiNWs, Gt-SiNW and CB-SiNW collected between 2theta 0 and 80 . The number in the legend is referring to the ICSD card. 

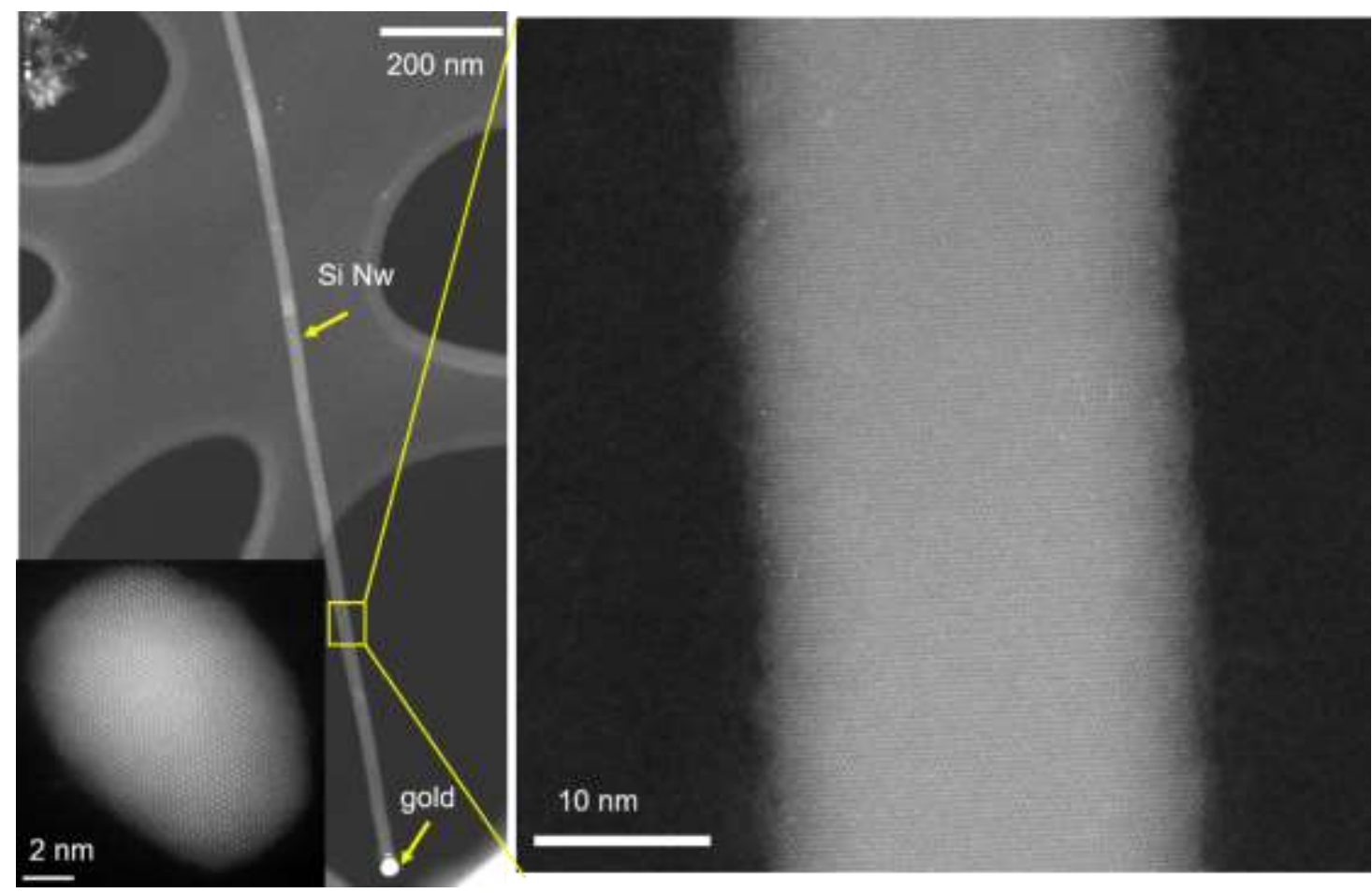

Figure S5. (a,b) STEM images of Gt-SiNW taken at an energy of $20 \mathrm{kV}$.

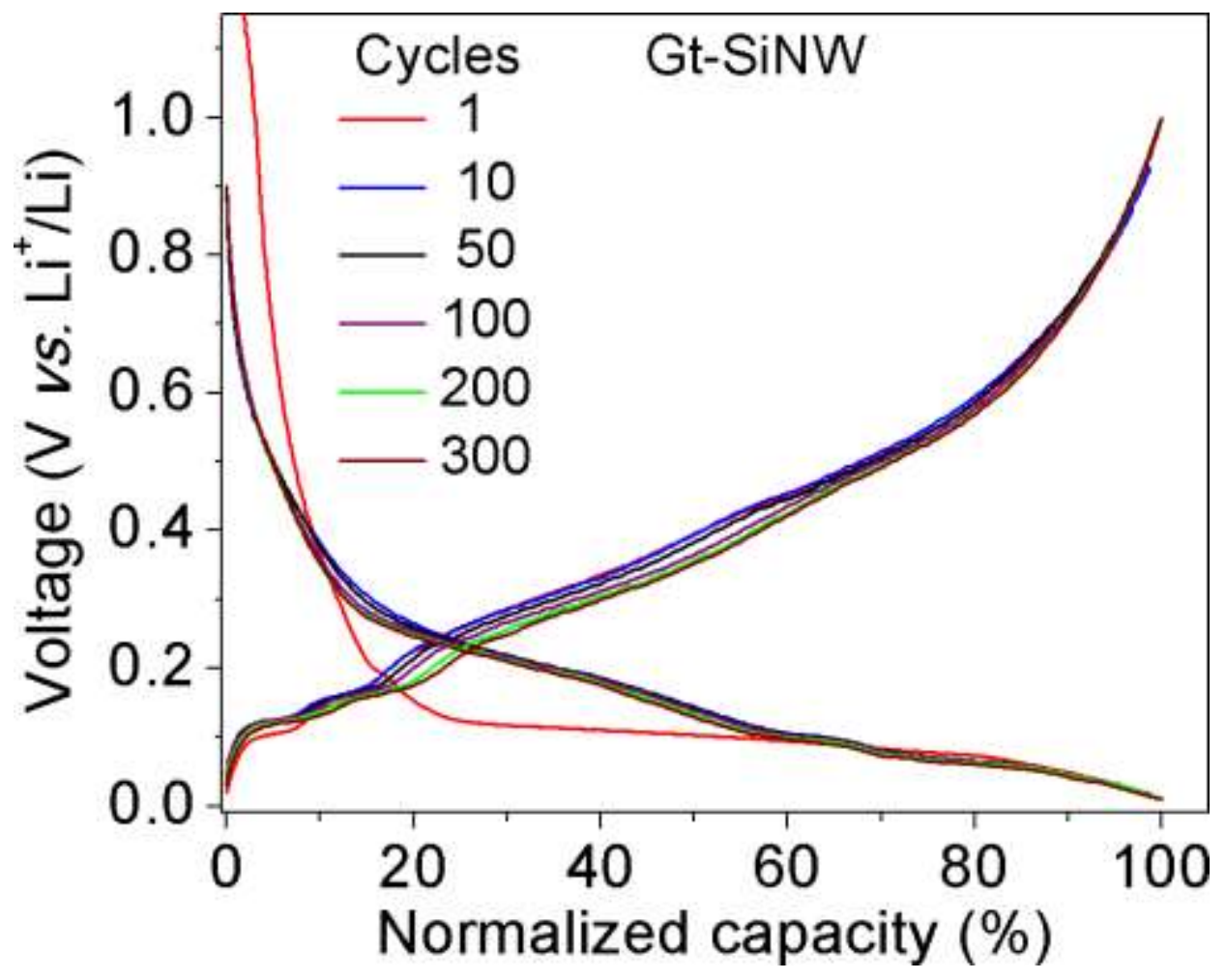

Figure S6. Charge-discharge profile (normalized only with galvanostatic capacity) of GtSiNW cycled at $0.2 \mathrm{C}$ rate using $1 \mathrm{M} \mathrm{LiPF}_{6}$ in $1: 1$ (v/v) EC: DEC with $2 \mathrm{wt} \% \mathrm{VC}$ and $10 \mathrm{wt} \%$ FEC as electrolyte. 

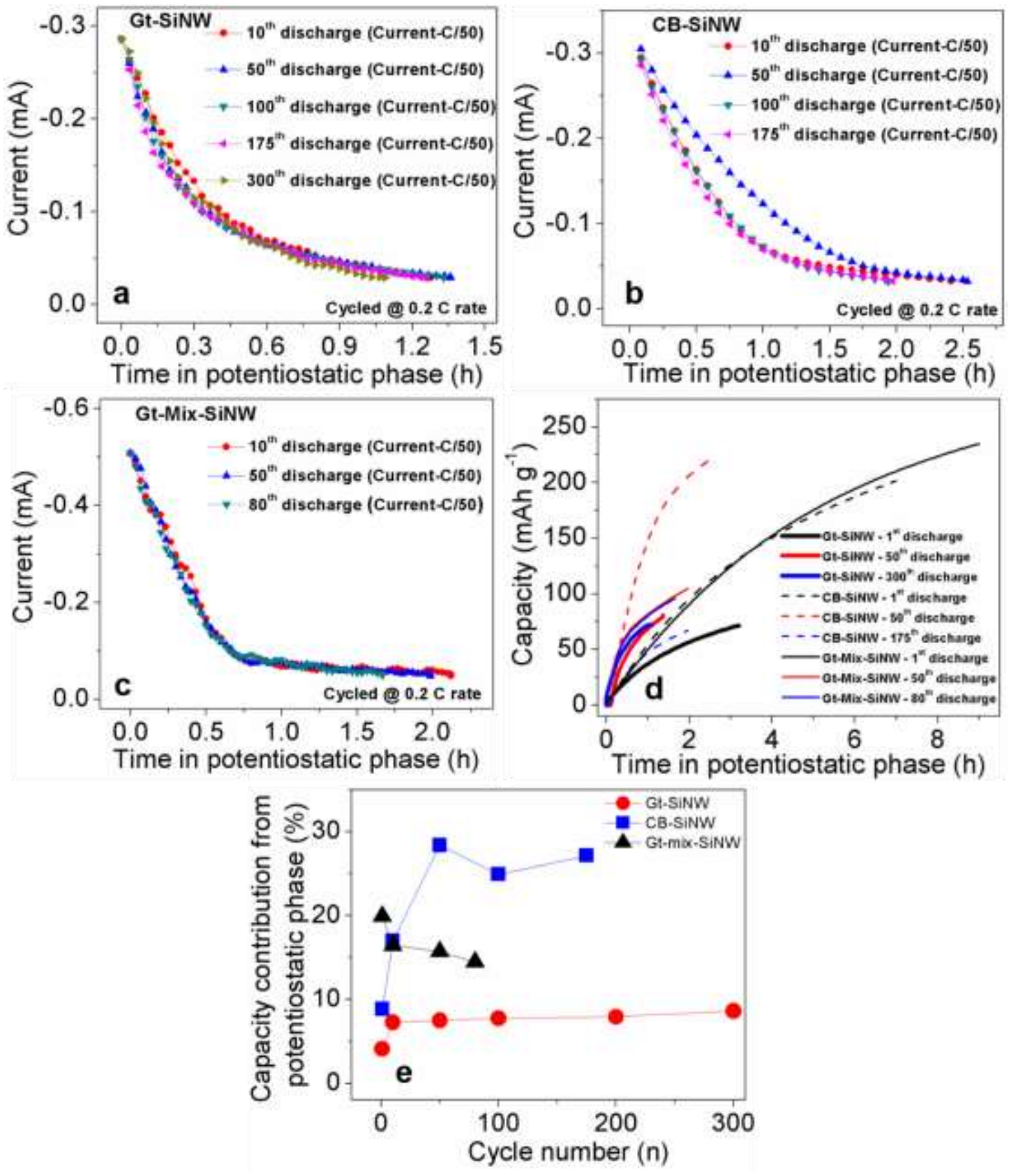

Figure S7. Current versus time profile of (a) Gt-SiNW, (b) CB-SiNW and (c) Gt-mix-SiNW in the potentiostatic step at $0.01 \mathrm{~V}$ with the maximum current limit of C/50. (d) Capacity obtained from potentiostatic phase versus time profile of all the composite anodes. (e) Capacity contribution from potentiostatic phase versus cycle number of all the composite anodes. 


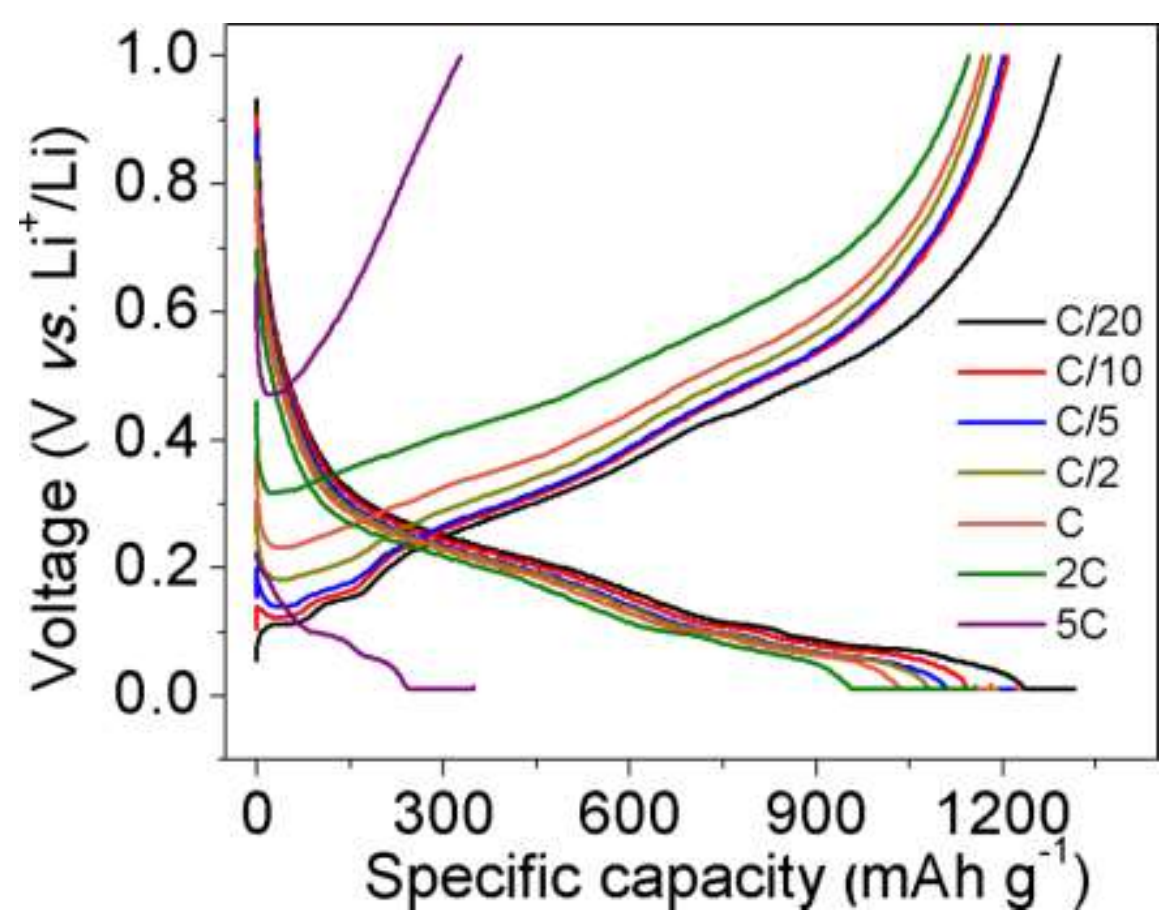

Figure S8. Charge/discharge profile of Gt-SiNW plotted as a function of the C-rate.

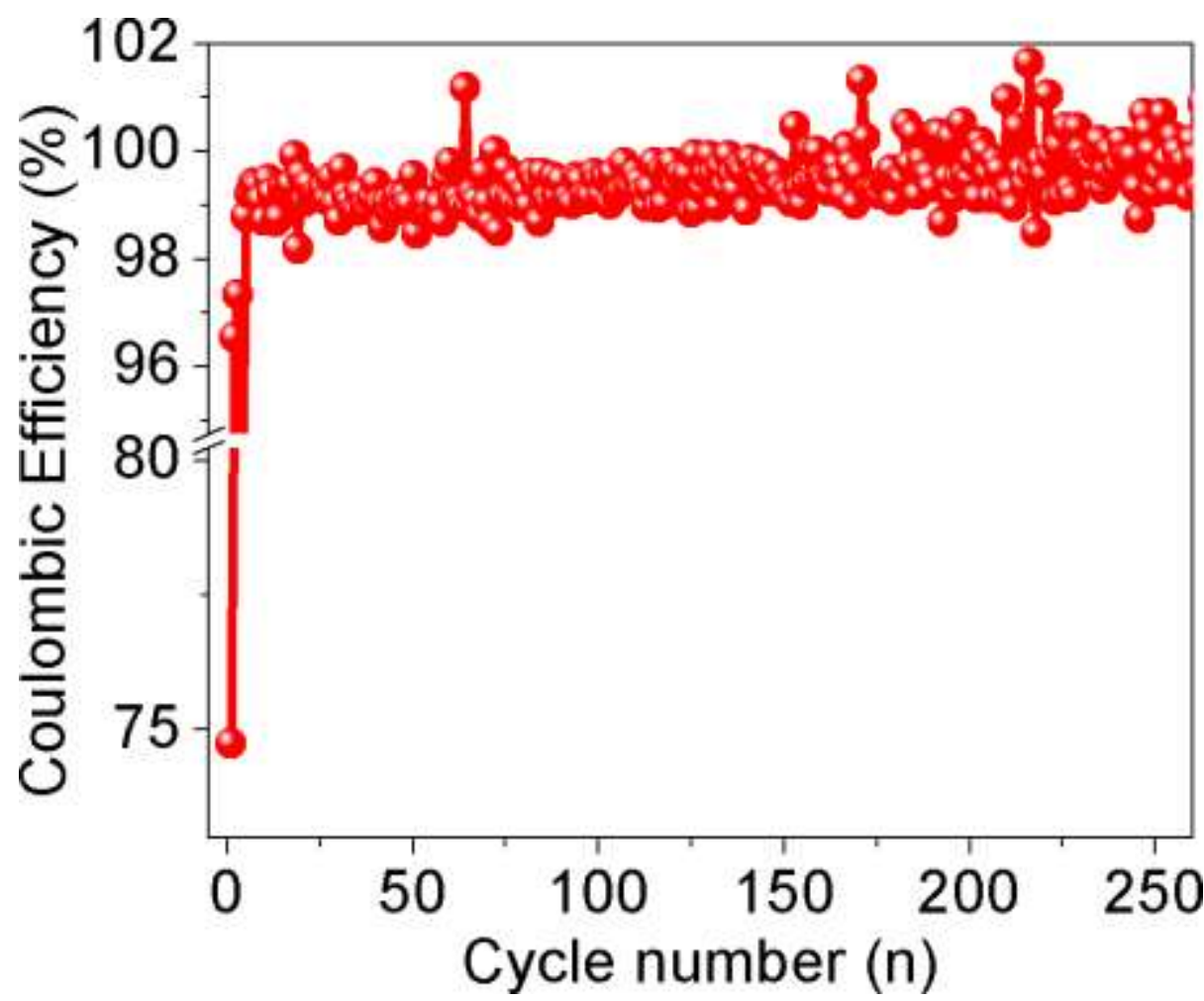

Figure S9. Coulombic efficiency behavior of Gt-SiNW at 2C. 


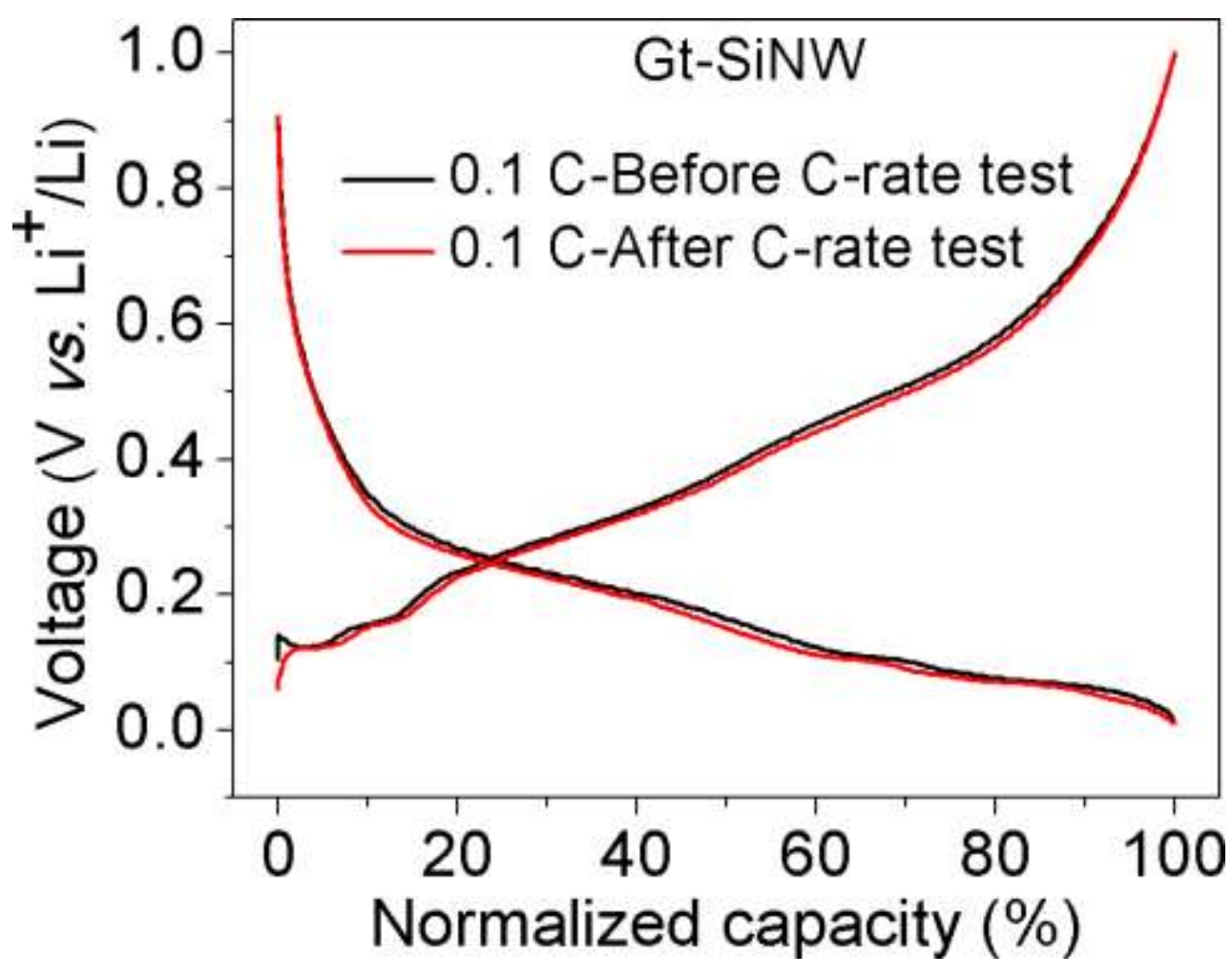

Figure S10. Charge-discharge profile (normalized only with galvanostatic capacity) of GtSiNW cycled at $0.1 \mathrm{C}$ rate before and after C-rate test using $1 \mathrm{M} \mathrm{LiPF}_{6}$ in 1:1 (v/v) EC: DEC with $2 \mathrm{wt} \% \mathrm{VC}$ and $10 \mathrm{wt} \%$ FEC as electrolyte.

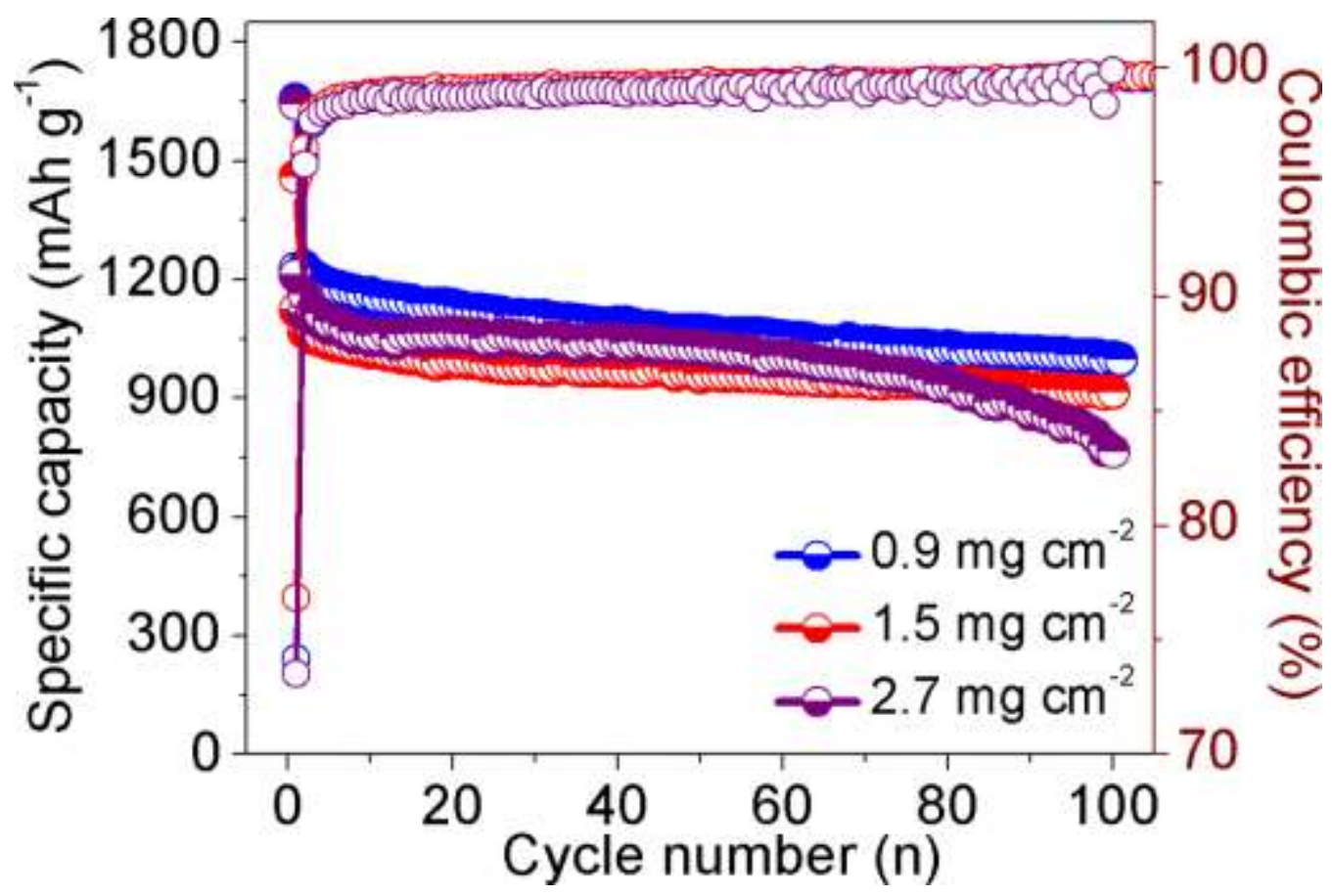

Figure S11. Specific capacity of Gt-SiNW anodes versus cycle number with different mass loadings from 0.9 to $2.7 \mathrm{mg} \mathrm{cm}^{-2}$ at $0.2 \mathrm{C}$ using $1 \mathrm{M} \mathrm{LiPF}_{6}$ in $1: 1(\mathrm{v} / \mathrm{v}) \mathrm{EC}$ : DEC with $2 \mathrm{wt} \%$ $\mathrm{VC}$ and $10 \mathrm{wt} \%$ FEC as electrolyte. 

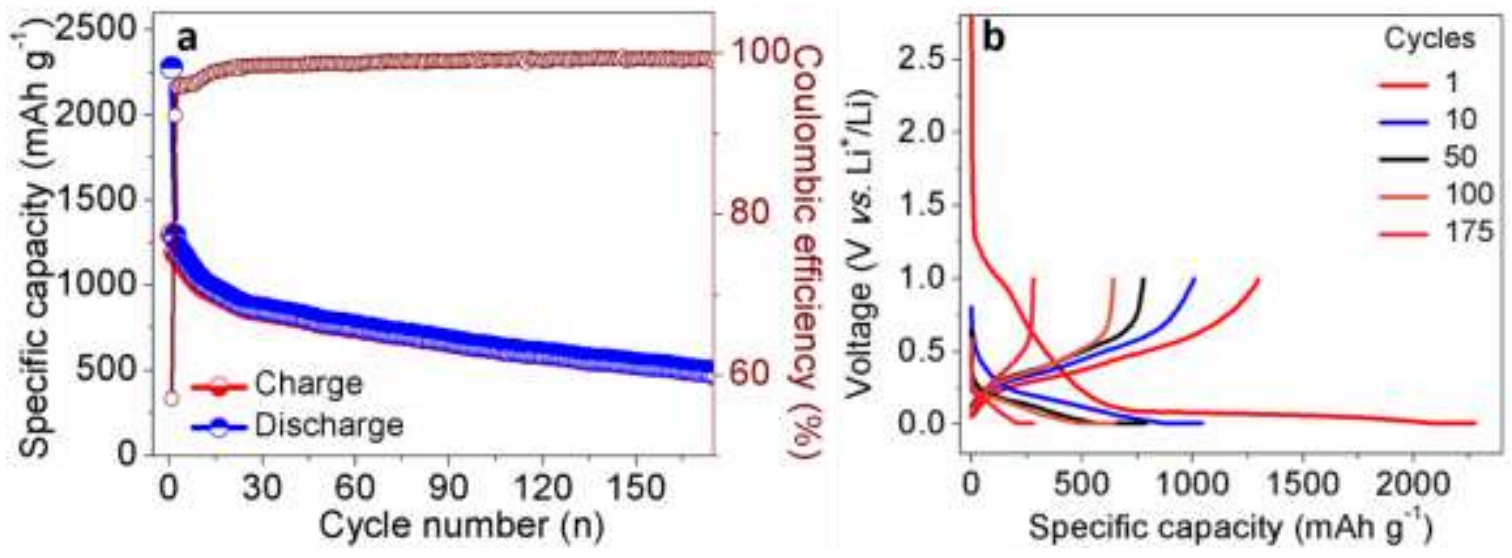

Figure S12. (a) Reversible charge/discharge capacity versus cycle number with corresponding Coulombic efficiency and (b) charge-discharge profile of CB-SiNW cycled at $0.2 \mathrm{C}$ rate at room temperature in the 0.01-1.0 potential window and with $1 \mathrm{M} \mathrm{LiPF}_{6}$ in 1:1 (v/v) EC: DEC with $2 \mathrm{wt} \% \mathrm{VC}$ and $10 \mathrm{wt} \%$ FEC electrolyte.

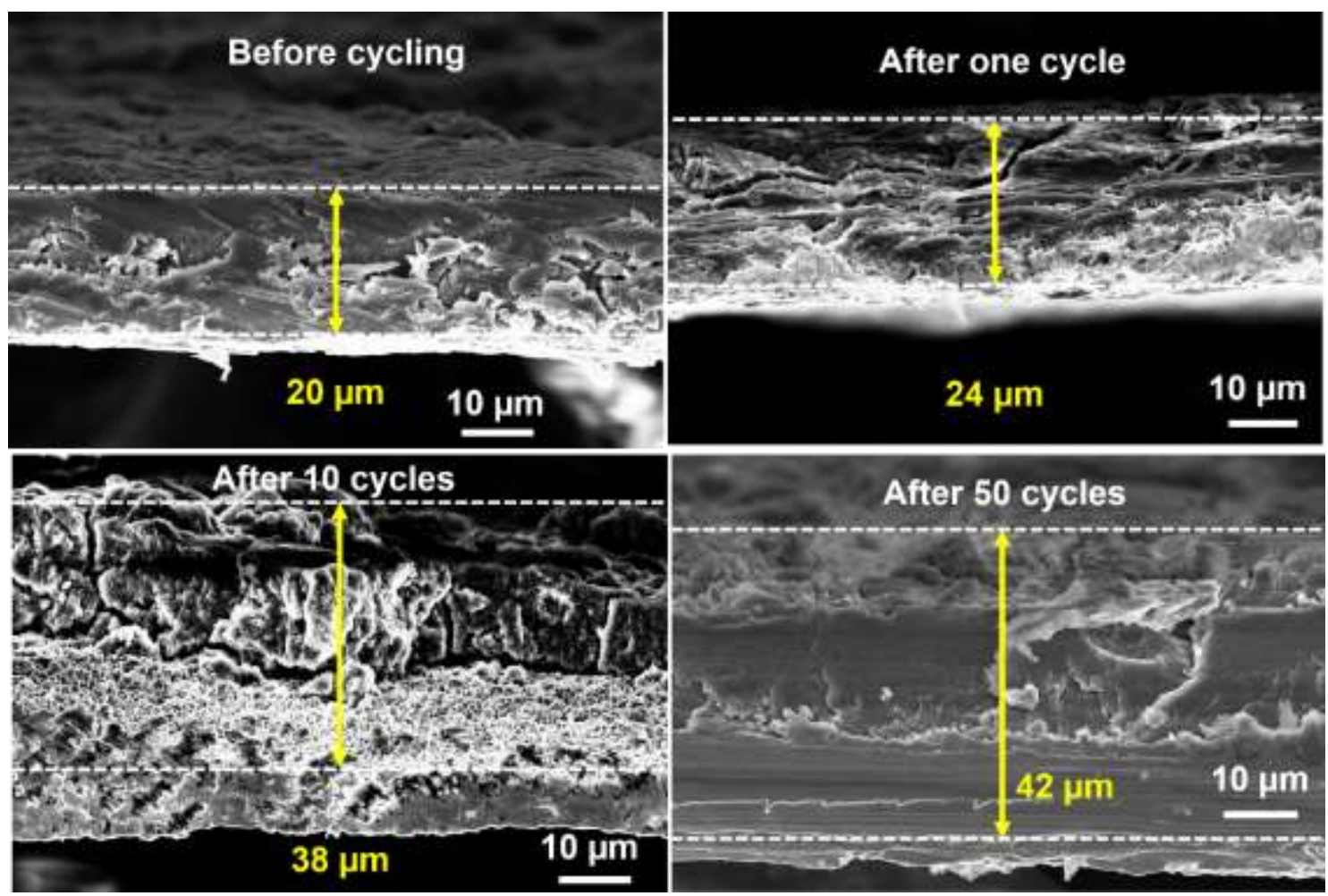

Figure S13. Cross sectional SEM view of Gt-SiNW electrodes (a) before cycling, and after 1 (b), 10 (c) and 50 (d) cycles at $0.2 \mathrm{C}$. 

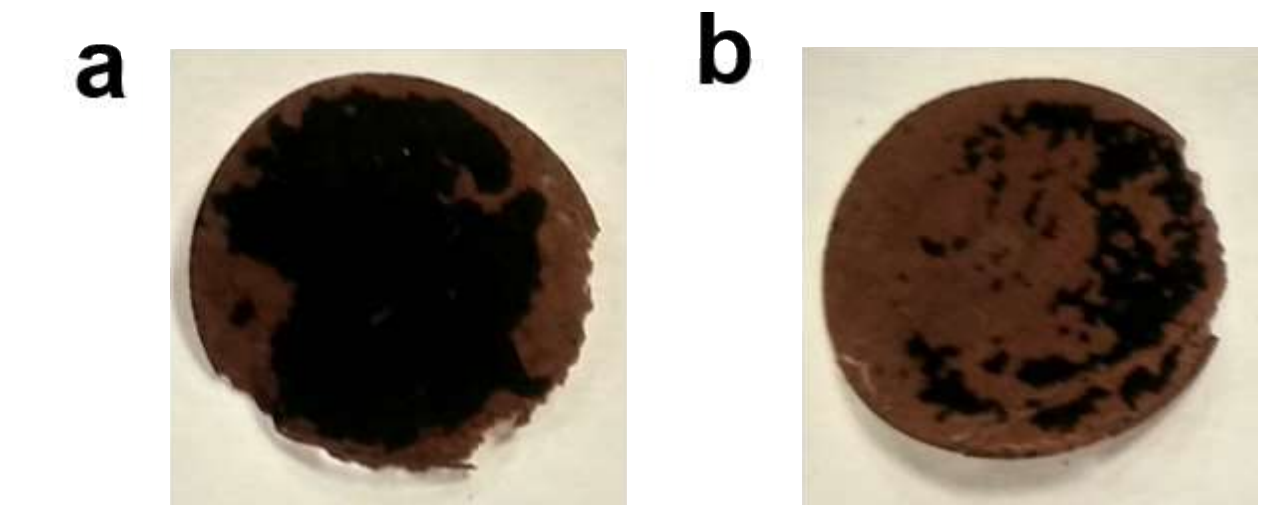

Figure S14. Photograph of CB-SiNW electrodes cycled at $0.2 \mathrm{C}$ after (a) 100 and (b) 200 cycles, respectively.
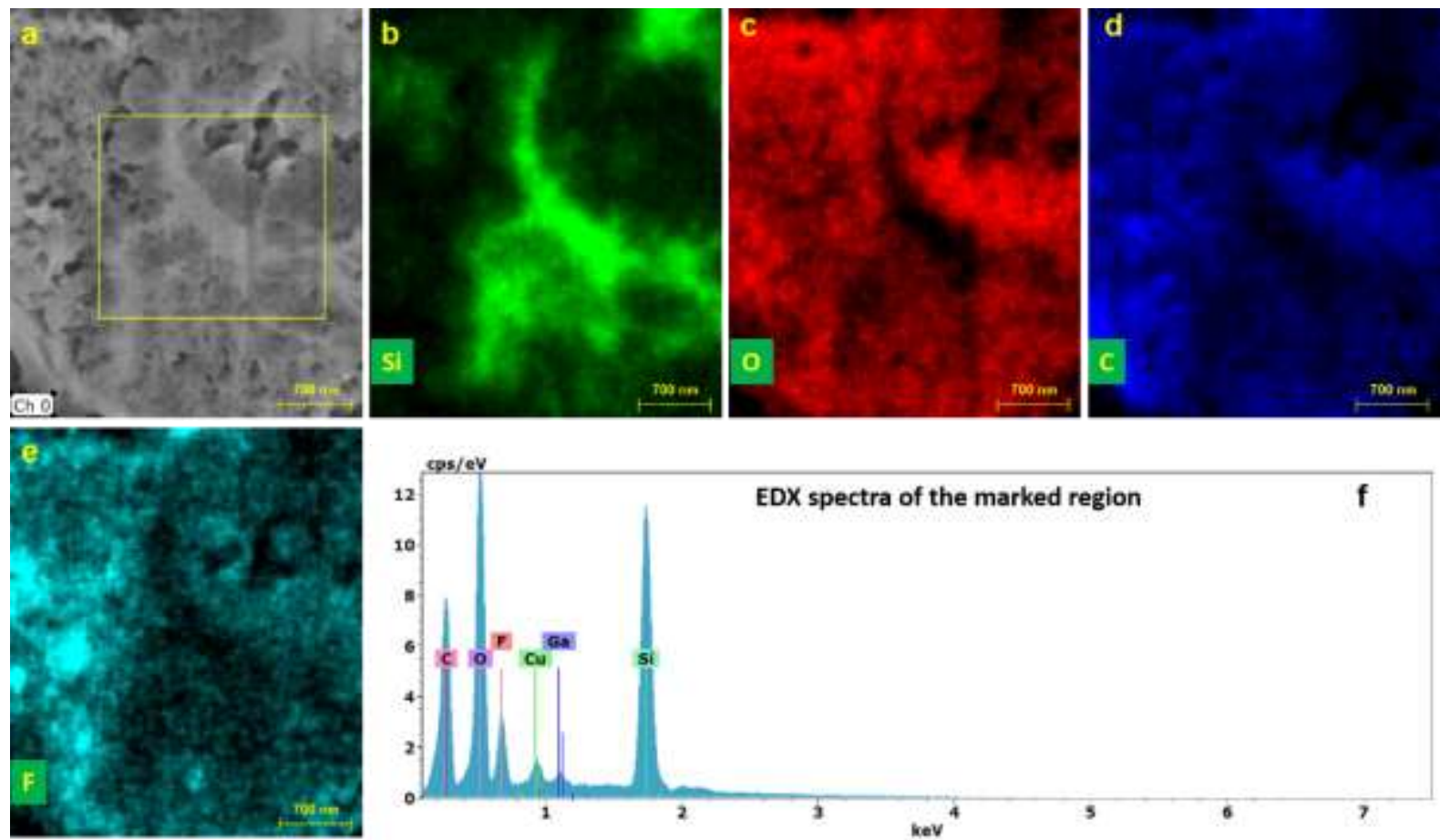

Figure S15. SEM-EDX chemical mapping of SiNW agglomerates in Gt-SiNW electrode after 200 cycles in the delithiated stage. $\mathrm{b}-\mathrm{e}$, individual mapping and distribution of elements $\mathrm{Si}, \mathrm{C}$, $\mathrm{O}$ and $\mathrm{F}$. f, EDX spectrum averaged over of the yellow box in fig 9 a. 

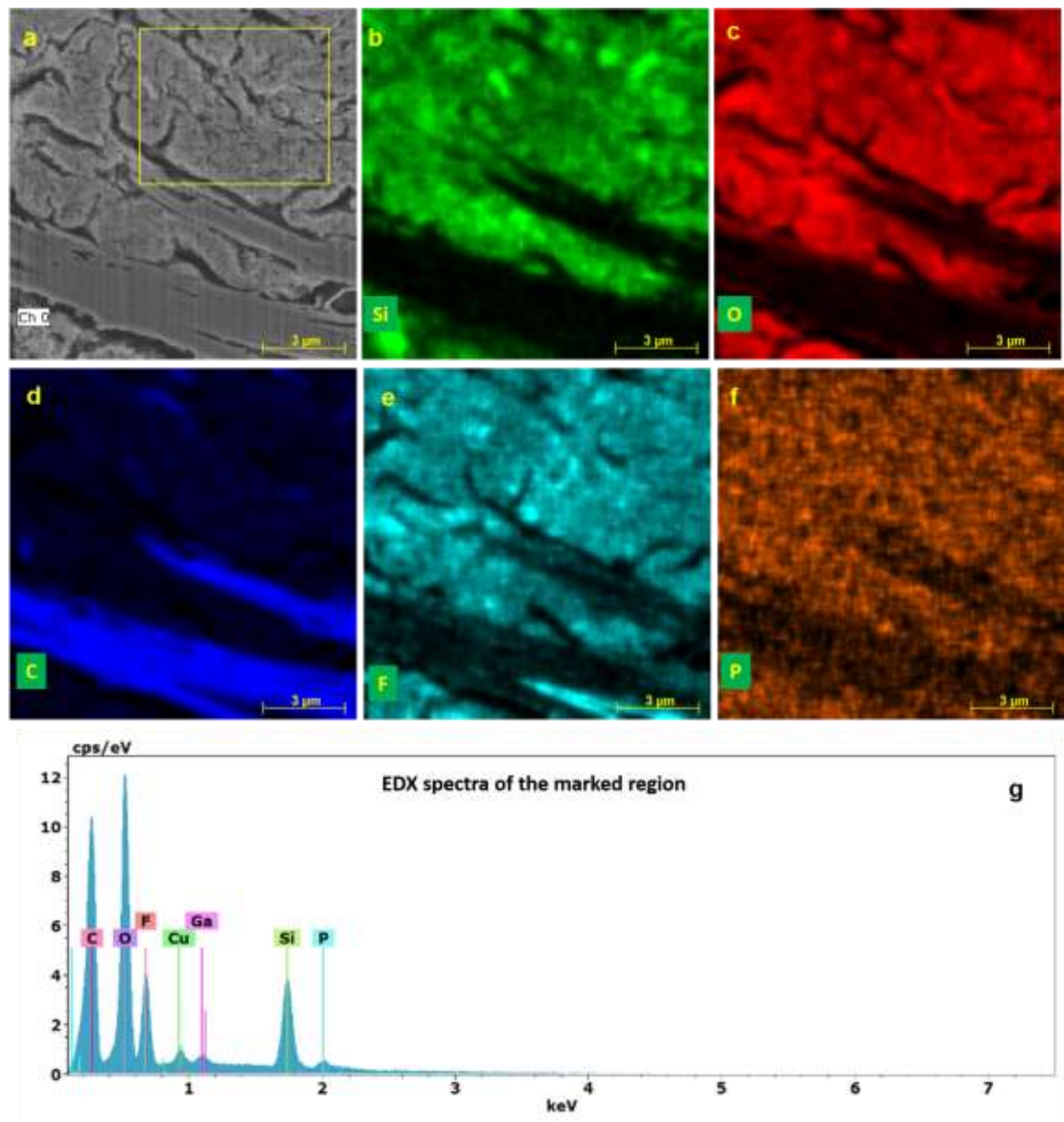

Figure S16. SEM-EDX elemental mapping of Gt-SiNW agglomerates/SEI region after 200 cycles in the delithiated stage. b-f, Elemental distribution of Si, C, O and F. g, EDX spectrum averaged over of the yellow box in Fig. 10 a.

\section{SEM-EDX on the aged Gt-SiNW electrode (200 cycles, delithiated sample)}

To get qualitative insights into the chemical evolution of the Gt-SiNW electrode after extended cycles, we have performed SEM-EDX (energy-dispersive X-ray) measurements on the FIB cut after 200 cycles in the delithiated stage. These measurements were carried out on a Zeiss Merlin microscope equipped with an EDX detector. Fig. $15(\mathrm{a}-\mathrm{e})$ present the SEM-EDX mapping and the corresponding EDX spectra obtained on the SiNW agglomerates showing a branch type morphology which is surrounded by a thick layer, probably composed of partially lithiated $\mathrm{Si}$, $\mathrm{Si}$ and SEI. It is evident that $\mathrm{Si}$ is mainly preserved in the core part as well as in the branches 
of the agglomerates, while the elements like $\mathrm{O}, \mathrm{C}$ and $\mathrm{F}$ were found as major constitutes of the SEI layer. Moreover, a small amount of Si can also be detected in the SEI phase. This clearly shows that the SEI is a very complex oxide phase. Fig. $16(\mathrm{a}-\mathrm{g})$ show the EDX maps obtained at the $\mathrm{Gt} / \mathrm{SiNW} / \mathrm{SEI}$ phase region. As expected, we have detected more $\mathrm{C}$ from the graphite (blue) particles as shown in Fig. 10 b. Noteworthy is the SiNW/SEI region, wherein significant amounts of $\mathrm{O}, \mathrm{F}, \mathrm{Si}, \mathrm{C}$ and $\mathrm{P}$ can be identified. It even appears that the SiNW/SEI phase consists of a mixture of both the SEI components and the Si.
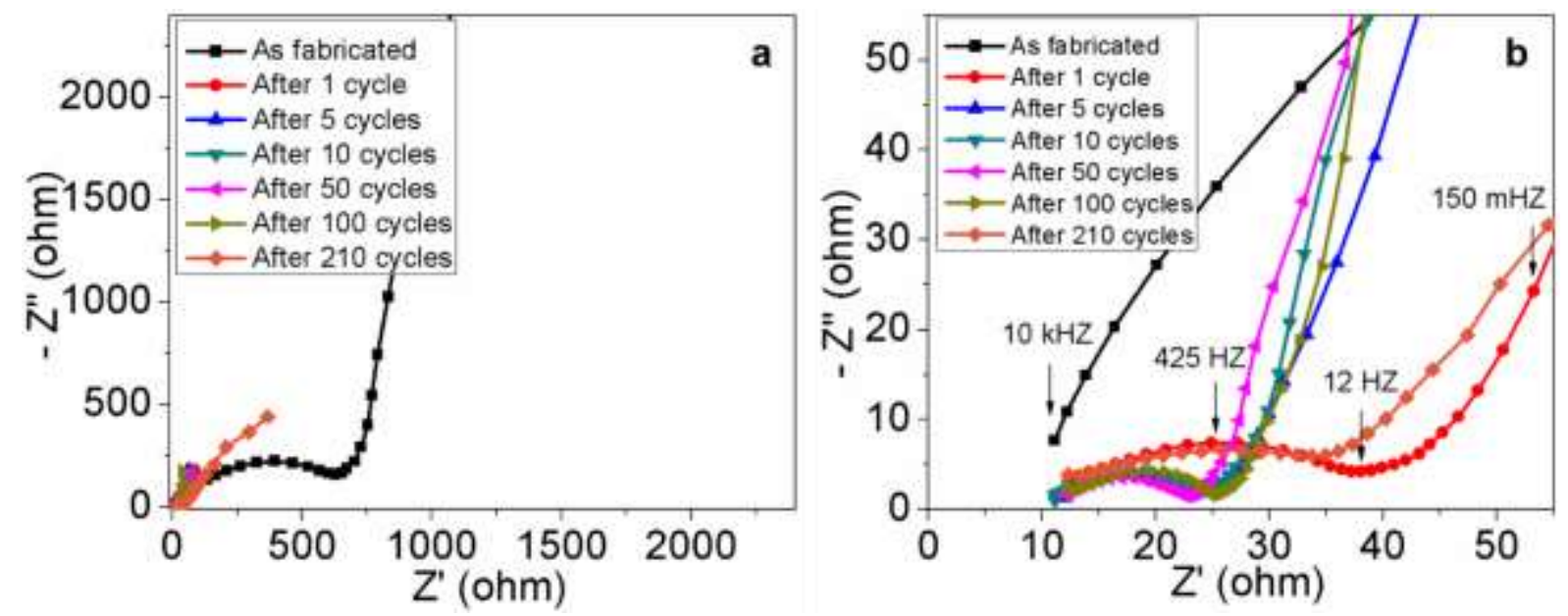

Figure S17. (a, b) Electrochemical Impedance Spectroscopy results of Gt-SiNW before and after cycling.

Equivalent circuit used to fit the EIS data (a) before and (b) after cycling.

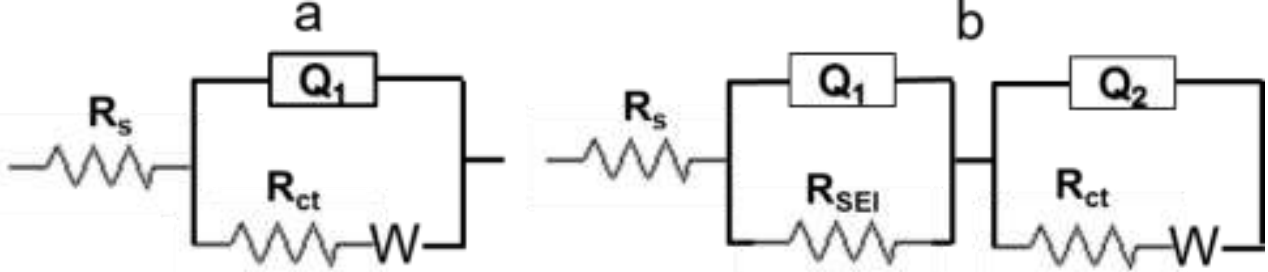

$\mathrm{R}_{\mathrm{s}}$-electrolyte resistance; $\mathrm{R}_{\mathrm{ct}}$-charge transfer resistance; $\mathrm{R}_{\mathrm{SEI}} \mathrm{SEI}$ resistance

$\mathrm{Q}_{1}$ and $\mathrm{Q}_{2}-$ Constant phase elements

W-Warburg impedance for the diffusion of $\mathrm{Li}^{+}$in the electrode 

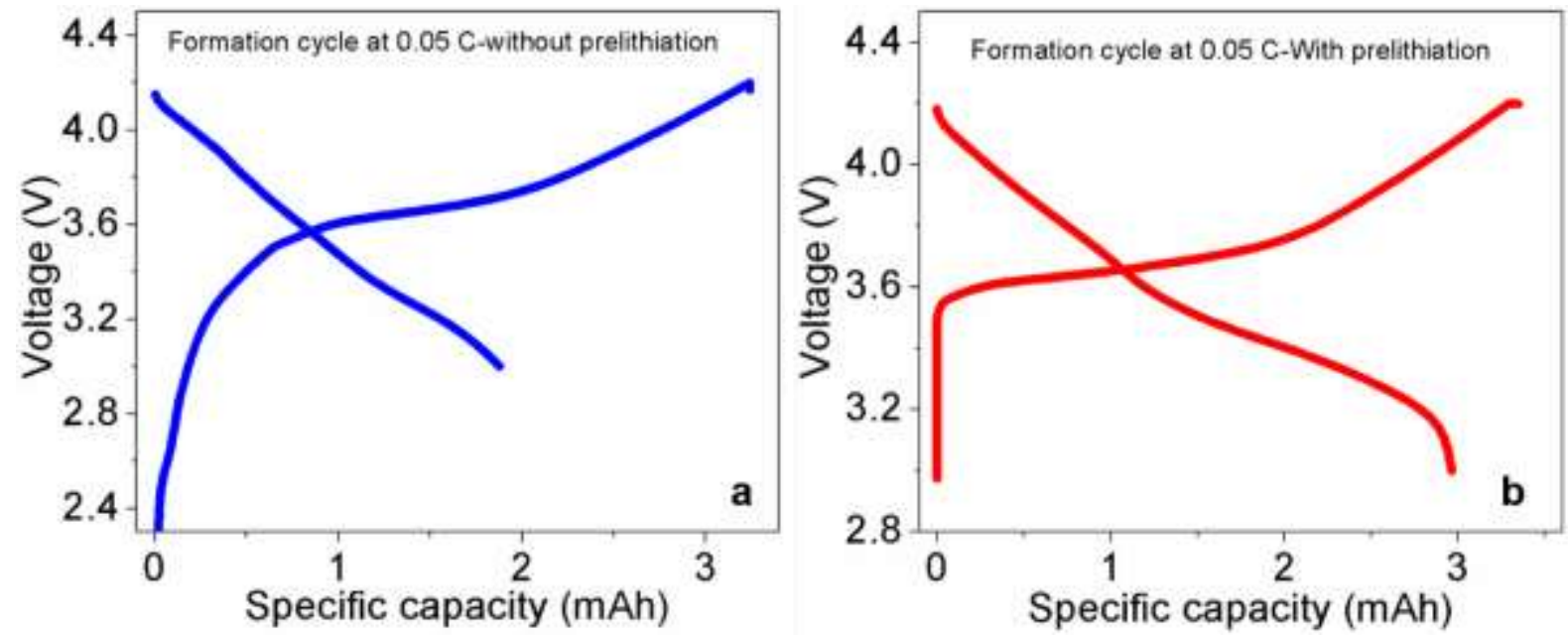

Figure S18. (a) Charge-discharge profile of the formation cycles of Gt-SiNW/NMC full cell (a) without and (b) with prelithiation cycled at $0.05 \mathrm{C}$ rate using $1 \mathrm{M} \mathrm{LiPF}_{6}$ in $1: 1$ (v/v) EC: DEC with $2 \mathrm{wt} \% \mathrm{VC}$ and $10 \mathrm{wt} \%$ FEC as electrolyte.
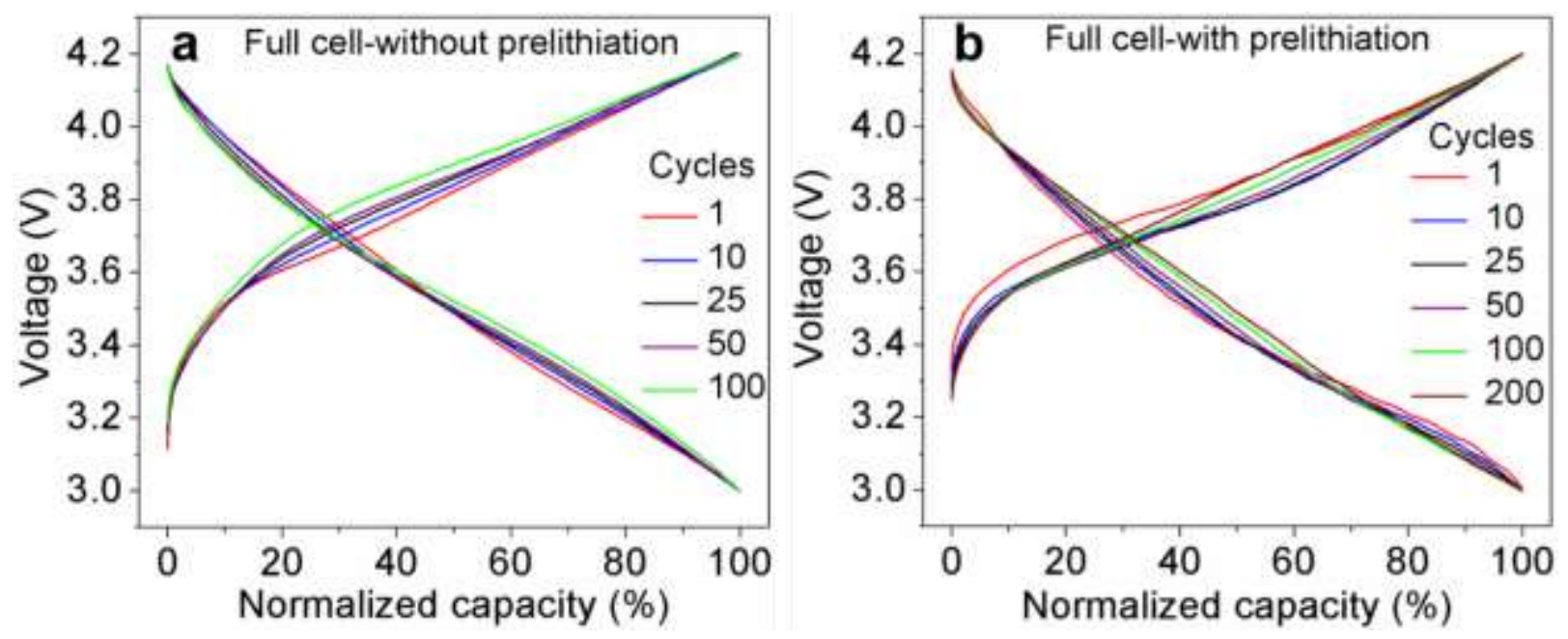

Figure S19. Charge-discharge profile (normalized only with galvanostatic capacity) of GtSiNW/NMC full cell (a) without prelithiation and (b) with prelithiation cycled at $0.5 \mathrm{C}$ rate using $1 \mathrm{M} \mathrm{LiPF}_{6}$ in 1:1 (v/v) EC: DEC with $2 \mathrm{wt} \% \mathrm{VC}$ and $10 \mathrm{wt} \% \mathrm{FEC}$ as electrolyte. 

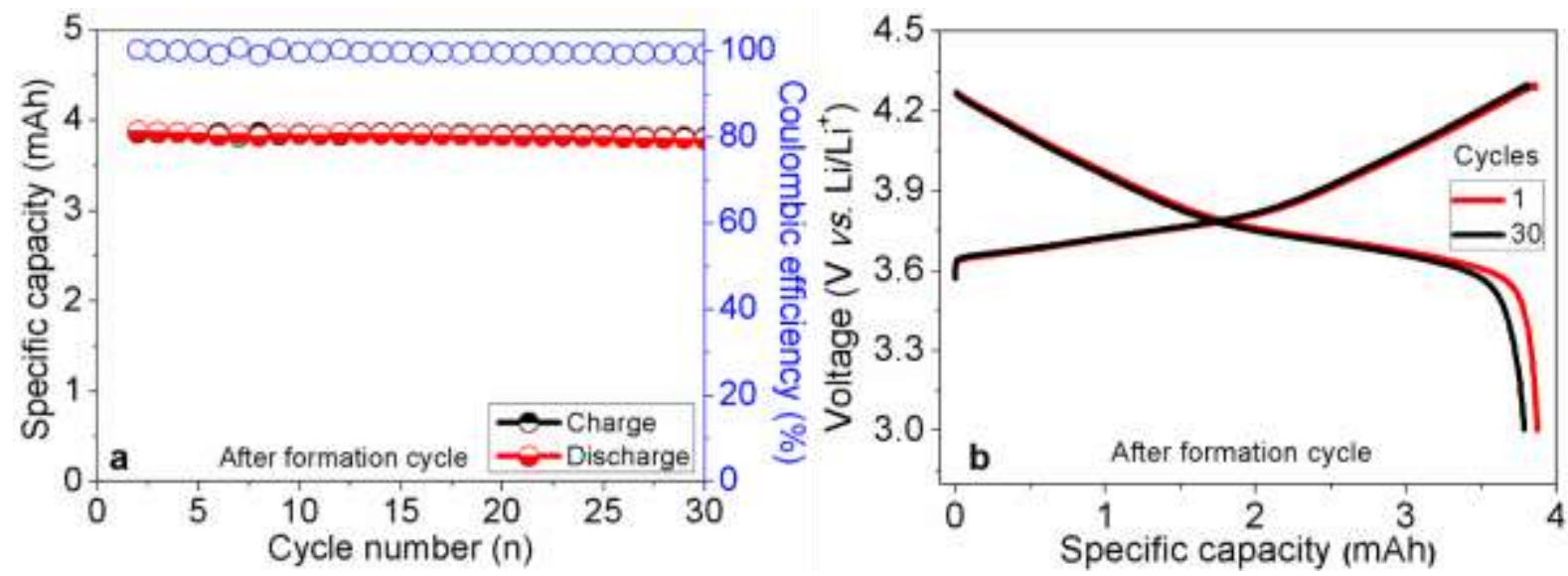

Figure S20. (a) Charge-discharge profile and (b) cyclability behavior of NMC-622 cathode investigated at a rate of $0.2 \mathrm{C}$ rate between 3 to $4.3 \mathrm{~V}$ vs $\mathrm{Li}^{+} / \mathrm{Li}$ using $1 \mathrm{M} \mathrm{LiPF}_{6}$ in EC/propylene carbonate/dimethyl carbonate (v/v/v 1:1:1) as electrolyte.

Table S1: Analysis of CHNS elements of Gt/SiNW samples

\begin{tabular}{|c|c|c|c|c|}
\hline \multirow{2}{*}{ Sample } & \multicolumn{2}{|c|}{ By elemental analysis CHNS } & \multicolumn{2}{c|}{ By weighing } \\
\cline { 2 - 5 } & $\mathrm{C}(\mathrm{wt} \%)$ & $\mathrm{Si}(\mathrm{wt} \%)$ & $\mathrm{C}(\mathrm{wt} \%)$ & $\mathrm{Si}(\mathrm{wt} \%)$ \\
\hline Pristine SiNW & $7.4 \pm 1$ & $80 \pm 2$ & - & - \\
\hline $\begin{array}{c}\text { Gt-SiNW } \\
(27 \mathrm{wt} \% \mathrm{Si})\end{array}$ & $72 \pm 2$ & $26 \pm 2$ & $70 \pm 2$ & $27 \pm 2$ \\
\hline $\begin{array}{c}\mathrm{Gt}-\mathrm{SiNW} \\
(32 \mathrm{wt} \% \mathrm{Si})\end{array}$ & $59 \pm 1$ & $32 \pm 1$ & $56 \pm 2$ & $36 \pm 2$ \\
\hline $\begin{array}{c}\mathrm{Gt}-\mathrm{SiNW} \\
(40 \mathrm{wt} \% \mathrm{Si})\end{array}$ & $49 \pm 1.5$ & $41 \pm 1.5$ & $46 \pm 2$ & $39 \pm 2$ \\
\hline
\end{tabular}


Table S2: Capacities of the materials taking into account to calculate the target capacity of the composite anodes (total mass of the electrode)

\begin{tabular}{|c|c|}
\hline \multicolumn{2}{|c|}{ Target specific capacity calculation for composite anodes } \\
\hline Sample & Specific capacity $\left(\mathrm{mAh}^{-1}\right)$ \\
\hline SiNWs & $\begin{array}{c}2500 \text { (based on the pristine SiNWs cycling result given } \\
\text { below) }\end{array}$ \\
\hline Graphite & 350 \\
\hline Carbon black & 150 \\
\hline $\mathrm{Au}$ & 510 \\
\hline
\end{tabular}

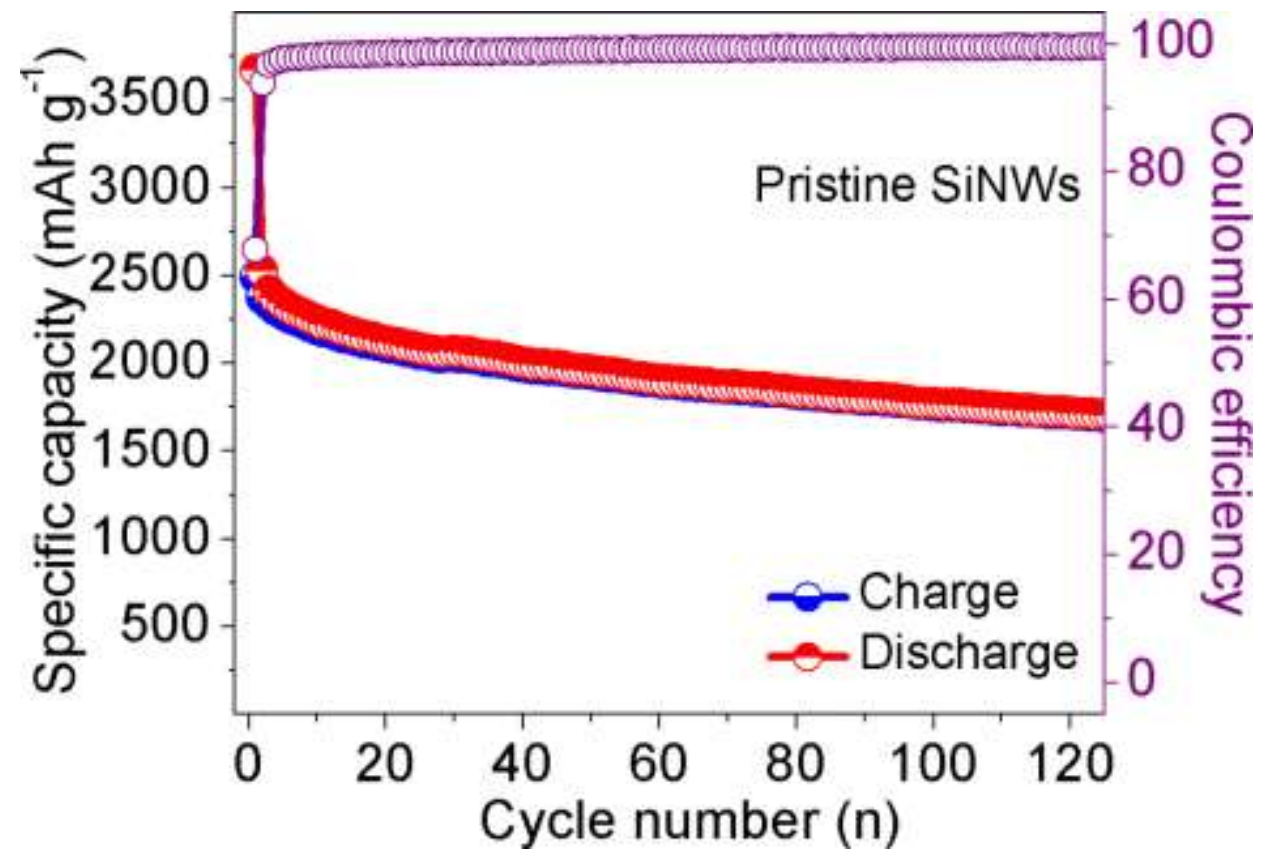

Cyclability behavior of pristine SiNW anode at $0.2 \mathrm{C}$ for 120 cycles.

Table S3: Detailed electrochemical testing of half and full cells

\begin{tabular}{|c|c|l|c|}
\hline \multicolumn{2}{|c|}{ Half-cell: Gt/CB-SiNW } \\
\hline \multirow{2}{*}{ Test } & Step & \multicolumn{1}{|c|}{ Conditions } & $\begin{array}{c}\text { Number of } \\
\text { cycles }\end{array}$ \\
\hline \multirow{4}{*}{\begin{tabular}{c} 
Cycle life test \\
\cline { 2 - 3 }
\end{tabular}} & Dis & $\mathrm{C} / 20->0.01 \mathrm{~V} / \mathrm{CV}<\mathrm{C} / 100 \& 100 \mathrm{~h}$ & \multirow{2}{*}{1} \\
\cline { 2 - 3 } & $\mathrm{Dis}$ & $\mathrm{C} / 20->1 \mathrm{~V} / 5-01 \mathrm{~V} / \mathrm{CV}<\mathrm{C} / 50 \& 50 \mathrm{~h}$ & \multirow{2}{*}{1} \\
\cline { 2 - 3 } $\begin{array}{c}\text { Extended cycle } \\
\text { life test }\end{array}$ & $\mathrm{Ch}$ & $\mathrm{C} / 5->1 \mathrm{~V}$ & \multirow{2}{*}{$\mathrm{C} / 20->0.01 \mathrm{~V} / \mathrm{CV}<\mathrm{C} / 100 \& 100 \mathrm{~h}$} \\
\cline { 2 - 3 } & $\mathrm{Ch}$ & $\mathrm{C} / 20->1 \mathrm{~V}$ & \\
\hline
\end{tabular}




\begin{tabular}{|c|c|c|c|}
\hline & Dis & $\mathrm{C} / 10->0.01 \mathrm{~V} / \mathrm{CV}<\mathrm{C} / 50 \& 50 \mathrm{~h}$ & \multirow{2}{*}{1} \\
\hline & $\mathrm{Ch}$ & $\mathrm{C} / 10->1 \mathrm{~V}$ & \\
\hline & Dis & $\mathrm{C} / 5->0.01 \mathrm{~V} / \mathrm{CV}<\mathrm{C} / 50 \& 50 \mathrm{~h}$ & \multirow{2}{*}{1} \\
\hline & $\mathrm{Ch}$ & $\mathrm{C} / 5->1 \mathrm{~V}$ & \\
\hline & Dis & $\mathrm{C} / 2->0.01 \mathrm{~V} / \mathrm{CV}<\mathrm{C} / 5 \& 10 \mathrm{~h}$ & \multirow{2}{*}{1} \\
\hline & $\mathrm{Ch}$ & $\mathrm{C} / 2->1 \mathrm{~V}$ & \\
\hline & Dis & $\mathrm{C} / 2->0.01 \mathrm{~V} / \mathrm{CV}<\mathrm{C} / 5 \& 10 \mathrm{~h}$ & \multirow{2}{*}{$>200$} \\
\hline & $\mathrm{Ch}$ & $2 \mathrm{C}->1 \mathrm{~V}$ & \\
\hline \multirow{18}{*}{ C-rate test } & Dis & $\mathrm{C} / 20->0.01 \mathrm{~V} / \mathrm{CV}<\mathrm{C} / 100 \& 100 \mathrm{~h}$ & \multirow{2}{*}{5} \\
\hline & $\mathrm{Ch}$ & $\mathrm{C} / 20->1 \mathrm{~V}$ & \\
\hline & Dis & $\mathrm{C} / 10->0.01 \mathrm{~V} / \mathrm{CV}<\mathrm{C} / 50 \& 50 \mathrm{~h}$ & \multirow{2}{*}{5} \\
\hline & $\mathrm{Ch}$ & $\mathrm{C} / 10->1 \mathrm{~V}$ & \\
\hline & Dis & $\mathrm{C} / 5->0.01 \mathrm{~V} / \mathrm{CV}<\mathrm{C} / 50 \& 50 \mathrm{~h}$ & \multirow{2}{*}{5} \\
\hline & $\mathrm{Ch}$ & $\mathrm{C} / 5$ - > $1 \mathrm{~V}$ & \\
\hline & Dis & $\mathrm{C} / 5->0.01 \mathrm{~V} / \mathrm{CV}<\mathrm{C} / 50 \& 50 \mathrm{~h}$ & \multirow{2}{*}{5} \\
\hline & $\mathrm{Ch}$ & $\mathrm{C} / 2->1 \mathrm{~V}$ & \\
\hline & Dis & $\mathrm{C} / 5->0.01 \mathrm{~V} / \mathrm{CV}<\mathrm{C} / 50 \& 50 \mathrm{~h}$ & \multirow{2}{*}{5} \\
\hline & $\mathrm{Ch}$ & $1 \mathrm{C}->1 \mathrm{~V}$ & \\
\hline & Dis & $\mathrm{C} / 5->0.01 \mathrm{~V} / \mathrm{CV}<\mathrm{C} / 50 \& 50 \mathrm{~h}$ & \multirow{2}{*}{5} \\
\hline & $\mathrm{Ch}$ & $2 \mathrm{C}->1 \mathrm{~V}$ & \\
\hline & Dis & $\mathrm{C} / 5->0.01 \mathrm{~V} / \mathrm{CV}<\mathrm{C} / 50 \& 50 \mathrm{~h}$ & \multirow{2}{*}{5} \\
\hline & $\mathrm{Ch}$ & $5 \mathrm{C}->1 \mathrm{~V}$ & \\
\hline & Dis & $\mathrm{C} / 10->0.01 \mathrm{~V} / \mathrm{CV}<\mathrm{C} / 50 \& 50 \mathrm{~h}$ & \multirow{2}{*}{5} \\
\hline & $\mathrm{Ch}$ & $\mathrm{C} / 10->1 \mathrm{~V}$ & \\
\hline & Dis & $\mathrm{C} / 5->0.01 \mathrm{~V} / \mathrm{CV}<\mathrm{C} / 50 \& 50 \mathrm{~h}$ & \multirow{2}{*}{$>200$} \\
\hline & $\mathrm{Ch}$ & $1 \mathrm{C}->1 \mathrm{~V}$ & \\
\hline \multirow{5}{*}{ Cycle life test } & & Half cell: NMC & \\
\hline & $\mathrm{Ch}$ & $\mathrm{C} / 20->4.3 \mathrm{~V} / \mathrm{CV}<\mathrm{C} / 100 \& 100 \mathrm{~h}$ & \multirow{2}{*}{1} \\
\hline & Dis & $\mathrm{C} / 20->3 \mathrm{~V}$ & \\
\hline & $\mathrm{Ch}$ & $\mathrm{C} / 2->4.3 \mathrm{~V} / \mathrm{CV}<\mathrm{C} / 50 \& 50 \mathrm{~h}$ & \multirow{2}{*}{$>50$} \\
\hline & Dis & $\mathrm{C} / 2->3 \mathrm{~V}$ & \\
\hline \multicolumn{4}{|c|}{ Prelithiation - Half cell: Gt-SiNW } \\
\hline Prelithiation & Dis & $\mathrm{C} / 20->0.01 \mathrm{~V} / \mathrm{CV}<\mathrm{C} / 100 \& 100 \mathrm{~h}$ & 1 \\
\hline \multicolumn{4}{|c|}{ Full cell: Gt-SiNW/NMC } \\
\hline \multirow{4}{*}{ Cycle life test } & $\mathrm{Ch}$ & $\mathrm{C} / 20->4.2 \mathrm{~V} / \mathrm{CV}<\mathrm{C} / 50 \& 50 \mathrm{~h}$ & \multirow{2}{*}{$\begin{array}{c}1 \\
\text { (formation } \\
\text { cycle) }\end{array}$} \\
\hline & Dis & $\mathrm{C} / 20->3 \mathrm{~V}$ & \\
\hline & $\mathrm{Ch}$ & $\mathrm{C} / 2->4.2 \mathrm{~V} / \mathrm{CV}<\mathrm{C} / 50 \& 50 \mathrm{~h}$ & \multirow{2}{*}{$>300$} \\
\hline & Dis & $\mathrm{C} / 2->3 \mathrm{~V}$ & \\
\hline
\end{tabular}




\section{Details of prelithation of Gt-SiNW in half cell configuration}

Gt-SiNW electrodes are coated with a mass loading of around $\sim 4-5 \mathrm{mg} / \mathrm{cm}^{2}$ to obtain a capacity of 5-6.5 mAh cm $\mathrm{cm}^{-2}$ (9-10 $\left.\mathrm{mAh}\right)$. This calculation is based on the ICE of the cell as well as capacity of the NMC cathode. Around 50 to $60 \%$ of the capacity of the respective Gt-SiNW is used for prelithiation with an aim to match the remaining capacity as $1: 1.1$ ratio (NMC/GtSiNW) with NMC-622 cathode. Gt-SiNW electrode is lithiated with Li metal electrode up to $0.01 \mathrm{~V}$ at $0.05 \mathrm{C}$ rate. We have fabricated more than 20 half-cells with different loadings to ensure the prelithiation step. Interestingly, all the full cells using the prelithiated Gt-SiNW anode exhibit almost similar electrochemical performances in terms of capacity, CE and cycling stability.

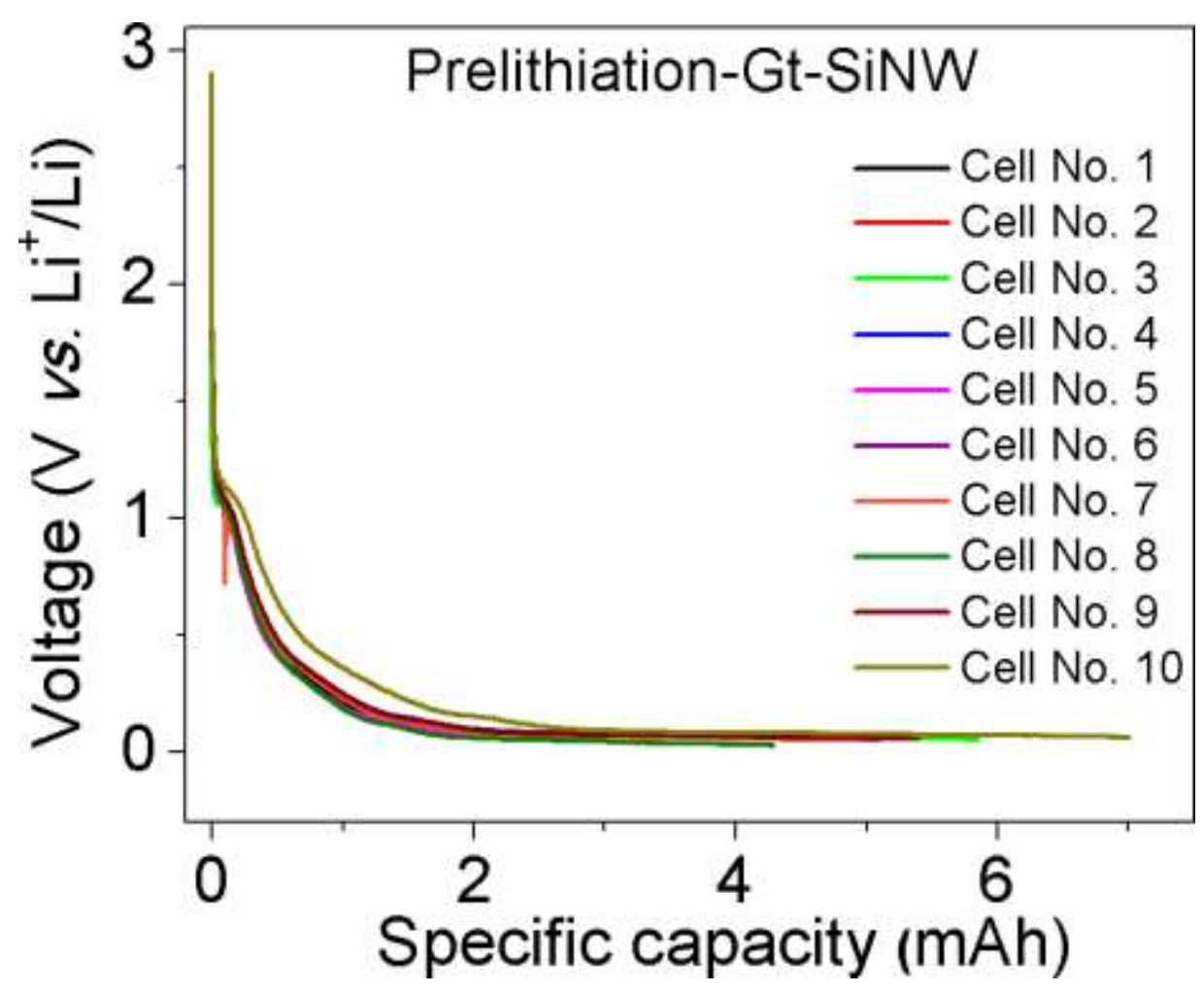

Discharge curve of Gt-SiNW anode cycled at $0.5 \mathrm{C}$ rate using $1 \mathrm{M} \mathrm{LiPF}_{6}$ in 1:1 (v/v) EC: DEC with $2 \mathrm{wt} \% \mathrm{VC}$ and $10 \mathrm{wt} \%$ FEC as electrolyte during prelithiation. 
Table S4: Comparison of parameters of recently reported various Si-Gt anodes

\section{References}

3 S. Zhu, J. Zhou, Y. Guan, W. Cai, Y. Zhao, Y. Zhu, L. Zhu, Y. Zhu and Y. Qian, Small, 2018, 14, 1802457.

4 M. N. Obrovac and V. L. Chevrier, Chem. Rev., 2014, 114, 11444-11502.

14 S. Jeong, J.-P. Lee, M. Ko, G. Kim, S. Park and J. Cho, Nano Lett., 2013, 13, $3403-$ 3407.

17 M. Ko, S. Chae, J. Ma, N. Kim, H.-W. Lee, Y. Cui and J. Cho, Nat Energy, 2016, 1, 16113.

18 X. Li, P. Yan, X. Xiao, J. H. Woo, C. Wang, J. Liu and J.-G. Zhang, Energy Environ. Sci., 2017, 10, 1427-1434.

19 S. Chae, M. Ko, S. Park, N. Kim, J. Ma and J. Cho, Energy Environ. Sci., 2016, 9, $1251-1257$.

20 S. Jiang, B. Hu, Z. Shi, W. Chen, Z. Zhang and L. Zhang, Advanced Functional Materials, 2020, 30, 1908558.

21 N. Kim, S. Chae, J. Ma, M. Ko and J. Cho, Nat Commun, 2017, 8, 812.

22 S. Y. Kim, J. Lee, B.-H. Kim, Y.-J. Kim, K. S. Yang and M.-S. Park, ACS Appl. Mater. Interfaces, 2016, 8, 12109-12117.

23 Q. Xu, J.-Y. Li, J.-K. Sun, Y.-X. Yin, L.-J. Wan and Y.-G. Guo, Adv. Energy Mater., $2017,7,1601481$.

24 H. Su, A. A. Barragan, L. Geng, D. Long, L. Ling, K. N. Bozhilov, L. Mangolini and J. Guo, Angewandte Chemie International Edition, 2017, 56, 10780-10785.

25 S. Kim, Y. K. Jeong, Y. Wang, H. Lee and J. W. Choi, Adv. Mater., 2018, 30, 1707594.

26 M. H. Parekh, A. D. Sediako, A. Naseri, M. J. Thomson and V. G. Pol, Advanced Energy Materials, 2020, 10, 1902799.

27 P. Li, J.-Y. Hwang and Y.-K. Sun, ACS Nano, 2019, 13, 2624-2633. 


\begin{tabular}{|c|c|c|c|c|c|c|c|c|c|c|c|}
\hline Synthesis & $\begin{array}{l}\text { Morphology } \\
\text { of Silicon }\end{array}$ & $\begin{array}{l}\text { Content } \\
\text { of } \mathrm{Si} \\
(\%)\end{array}$ & $\begin{array}{c}\text { Mass } \\
\text { loading } \\
\left(\mathrm{mg} \mathrm{cm}^{-2}\right)\end{array}$ & $\begin{array}{c}\text { Electrode } \\
\text { density } \\
\left(\mathrm{g} \mathrm{cm}^{-3}\right)\end{array}$ & Electrolyte & $\begin{array}{l}\text { Electrode } \\
\text { composition } \\
\text { (Active Mat: } \\
\text { Carbon: } \\
\text { Binder) }\end{array}$ & 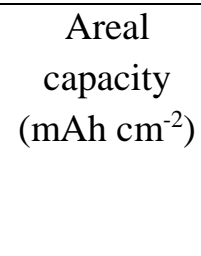 & $\begin{array}{c}\text { Test } \\
\text { condition }\end{array}$ & $\begin{array}{c}\text { Cycling } \\
\left(\mathrm{mAh} \mathrm{g}^{-1}\right)\end{array}$ & $\begin{array}{c}\mathrm{IC} \\
\mathrm{E} \\
(\%)\end{array}$ & Rate capacity \\
\hline This work & Nanowires & 32 & 0.9-2.7 & $1-1.3$ & $\begin{array}{c}\text { 1. M LiPF } \\
\text { EC/DECMC (1 :1, } \\
\text { v/v) + 10\% } \\
\text { FEC+2wt\% VC }\end{array}$ & 80/10/10 & $1.2-4.0$ & $\begin{array}{c}0.01 \text { to } 1 \\
V \text { at } 0.5 \mathrm{C}\end{array}$ & $\begin{array}{l}940 \text { after } \\
200 \text { cycles }\end{array}$ & 72 & $\begin{array}{c}1290 \text { at } 0.05 C \\
1208 \text { at } 0.1 C \\
1201 \text { at } 0.2 \mathrm{C} \\
1178 \text { at } 0.5 \mathrm{C} \\
1168 \text { at } 1 \mathrm{C} \\
1145 \text { at } 2 \mathrm{C} 327 \\
\text { at } 5 \mathrm{C}\end{array}$ \\
\hline $\begin{array}{c}\text { Ball milling + } \\
\text { annealing } \\
\text { Ref. } 3\end{array}$ & Nanoparticle & $5 / 10 / 15$ & 1.1 & - & $\begin{array}{c}1 \mathrm{M} \mathrm{LiPF}_{6} \text { in } \\
\mathrm{EC} / \mathrm{DEC}(1: 1, \mathrm{v} / \mathrm{v})+ \\
5 \% \text { FEC }\end{array}$ & 60:20:20 & & $\begin{array}{l}0.005 \text { to } \\
1.5 \mathrm{~V} \text { at } \\
\text { various } \\
\text { current } \\
\text { densitties }\end{array}$ & $\begin{array}{c}548 \text { after } 100 \\
\text { cycles }\end{array}$ & $\begin{array}{c}75 \\
6 / 7 \\
2.5 / \\
75 \\
9\end{array}$ & $\begin{array}{l}523 \text { at } 1 \mathrm{C} \\
467 \text { at } 2 \mathrm{C} \\
388 \text { at } 4 \mathrm{C} \\
310 \text { at } 6 \mathrm{C}\end{array}$ \\
\hline $\begin{array}{c}\text { Spray drying + } \\
\text { CVD } \\
\text { Ref. } 4\end{array}$ & Nanolayer & 6 & 7 & 1.6 & $\begin{array}{l}1.3 \mathrm{M} \mathrm{LiPF}_{6} \text { in } \\
\mathrm{EC} / \mathrm{EMC} / \mathrm{DEC} \\
(3 / 5 / 2, \mathrm{v} / \mathrm{v} / \mathrm{v})+0.2 \% \\
\mathrm{LiBF}_{4}+10 \% \mathrm{FEC} \\
+0.5 \% \mathrm{VC}+1 \% \mathrm{PS}\end{array}$ & $96: 1: 3$ & & $\begin{array}{c}0.005 \text { to } \\
1.5 \mathrm{~V} \text { at } \\
0.5 \mathrm{C}\end{array}$ & $\begin{array}{c}537 \text { after } 50 \\
\text { cycles }\end{array}$ & $\begin{array}{c}90 . \\
9\end{array}$ & $\begin{array}{l}500 \text { at } 1 \mathrm{C} \\
329 \text { at } 5 \mathrm{C}\end{array}$ \\
\hline $\begin{array}{l}\text { Etching + } \\
\text { VLS process } \\
\text { Ref. } 14\end{array}$ & Nanowire & 20 & - & 1.5 & $\begin{array}{l}1.15 \mathrm{M} \mathrm{LiPF}_{6} \\
\mathrm{EC} / \mathrm{DMC} / \mathrm{EMC} \\
(3: 4: 3, \mathrm{v} / \mathrm{v} / \mathrm{v})+5 \% \\
\mathrm{FEC}\end{array}$ & $85: 0: 15$ & - & $\begin{array}{c}0.005 \text { to } \\
1.5 \mathrm{~V} \text { at } \\
0.05 \mathrm{C}\end{array}$ & $\begin{array}{c}675 \text { after } 100 \\
\text { cycles }\end{array}$ & 91 & $\begin{array}{l}704 \text { at } 0.2 \mathrm{C} \\
562 \text { at } 1 \mathrm{C} \\
500 \text { at } 3 \mathrm{C} \\
384 \text { at } 5 \mathrm{C}\end{array}$ \\
\hline $\begin{array}{l}\text { CVD } \\
\text { Ref. } 17\end{array}$ & Nanolayer & 6 & 6.5 & 1.6 & $\begin{array}{c}1.3 \mathrm{M} \mathrm{LiPF}_{6} \text { in } \\
\mathrm{EC} / \mathrm{DEC}(3: 7, \mathrm{v} / \mathrm{v})+ \\
10 \% \mathrm{FEC}\end{array}$ & $95.8 / 3.2 / 1$ & $\begin{array}{l}3.36 \text { after } \\
100 \text { cycles }\end{array}$ & $\begin{array}{c}0.005 \text { to } \\
1.5 \mathrm{~V} \text { at } \\
0.5 \mathrm{C}\end{array}$ & $\begin{array}{c}517 \text { after } 100 \\
\text { cycles }\end{array}$ & 92 & $\begin{array}{c}510 \text { at } 0.5 \mathrm{C} \\
491 \text { at } 1 \mathrm{C} \\
336 \text { at } 3 \mathrm{C} \\
207 \text { at } 5 \mathrm{C}\end{array}$ \\
\hline
\end{tabular}




\begin{tabular}{|c|c|c|c|c|c|c|c|c|c|c|c|}
\hline $\begin{array}{c}\text { Electrochemic } \\
\text { al etching }+ \\
\text { CVD } \\
\text { Ref. } 18\end{array}$ & Si wafer & $10 / 25$ & $\begin{array}{c}3(\mathrm{mAh} \\
\left.\mathrm{cm}^{-2}\right)\end{array}$ & - & $\begin{array}{c}\mathrm{M} \mathrm{LiPF}_{6} \text { in } \\
\mathrm{EC} / \mathrm{DEC}(1: 1, \mathrm{v} / \mathrm{v})+ \\
10 \mathrm{wt} \% \mathrm{FEC}\end{array}$ & $75: 5: 20$ & $\begin{array}{c}2.0 \text { after } \\
535 \text { cycles }\end{array}$ & $\begin{array}{l}0.005 \text { to } \\
1.5 \mathrm{~V} \text { at } \\
0.4 \mathrm{~mA} \\
\mathrm{~cm}^{-2}\end{array}$ & $\begin{array}{c}650 \text { after } 450 \\
\text { cycles }\end{array}$ & 63 & - \\
\hline $\begin{array}{l}\text { Spray drying + } \\
\text { Annealing } \\
\text { Ref. 19 }\end{array}$ & $\begin{array}{c}\text { Alloy } \\
(\mathrm{Fe}-\mathrm{Cu}-\mathrm{Si})\end{array}$ & 7 & 8.5 & 1.6 & $\begin{array}{c}1.3 \mathrm{M} \mathrm{LiPF}_{6} \\
\mathrm{EC}^{\mathrm{EMC} / \mathrm{DEC}} \\
(3 / 5 / 2, \mathrm{v} / \mathrm{v} / \mathrm{v})+10 \% \\
\mathrm{FEC}+0.5 \% \mathrm{VC}\end{array}$ & $97: 0: 3$ & $1-3.44$ & $\begin{array}{c}0.01 \text { to } \\
2.0 \mathrm{~V} \text { at } \\
0.5 \mathrm{C} \\
\text { with CC- } \\
\mathrm{CV} \text { mode }\end{array}$ & $\begin{array}{c}420 \text { after } 50 \\
\text { cycles }\end{array}$ & $\begin{array}{c}91 . \\
4\end{array}$ & $\begin{array}{c}2 \mathrm{mAh} \mathrm{cm}^{-2} \text { at } \\
1 \mathrm{C}\end{array}$ \\
\hline $\begin{array}{c}\text { Physical } \\
\text { blending } \\
\text { Ref. } 20\end{array}$ & Nanoparticle & 15 & 2.4 & - & $\begin{array}{c}1.2 \mathrm{M} \text { LiPF6 in } \\
\text { EC/EMC (3:7 wt/wt) } \\
+10 \mathrm{wt} \% \mathrm{FEC}\end{array}$ & $88: 2: 10$ & 1.37 & $\begin{array}{c}0.005 \text { to } \\
1.0 \mathrm{~V} \text { at } \\
\mathrm{C} / 3\end{array}$ & $\begin{array}{c}571 \text { after } 100 \\
\text { cycles }\end{array}$ & $\begin{array}{c}97 . \\
1\end{array}$ & - \\
\hline $\begin{array}{l}\text { Hydrogenation } \\
\text { +CVD } \\
\text { Ref. } 21\end{array}$ & Nanolayer & & - & 1.6 & $\begin{array}{c}1.3 \mathrm{M} \mathrm{LiPF} \text { in } \\
\mathrm{EC} / \mathrm{EMC}^{\mathrm{MMC}} \\
(3 / 5 / 2, \mathrm{v} / \mathrm{v} / \mathrm{v})+10 \% \\
\mathrm{FEC}+0.2 \% \mathrm{LiBF}_{4}+ \\
0.5 \% \mathrm{VC}+3 \% \\
\text { succinonitrile }+1 \% \\
\text { of propane sultone }\end{array}$ & $96: 1: 3$ & 3.5 & $\begin{array}{c}0.005 \text { to } \\
1.0 \mathrm{~V} \text { at } \\
1.75 \mathrm{~mA} \\
\mathrm{~cm}^{-2} \mathrm{with} \\
\mathrm{CC}-\mathrm{CV} \\
\text { mode }\end{array}$ & $\begin{array}{c}521 \text { after } 50 \\
\text { cycles }\end{array}$ & $\begin{array}{c}93 . \\
8\end{array}$ & $\begin{array}{c}100 \text { at } 10.5 \mathrm{~mA} \\
\mathrm{~cm}^{-2}\end{array}$ \\
\hline $\begin{array}{l}\text { Carbonization } \\
\text { Ref. } 22\end{array}$ & Nanoparticle & $\begin{array}{c}12 / 17 / 2 \\
1\end{array}$ & 1.5 & - & $\begin{array}{l}1 \mathrm{M} \mathrm{LiPF}_{6} \text { in } \\
\mathrm{EC} / \mathrm{DMC}(3: 7, \mathrm{v} / \mathrm{v})\end{array}$ & $80: 10: 10$ & $\begin{array}{l}1.06 \text { after } \\
50 \text { cycles }\end{array}$ & $\begin{array}{c}0.01 \text { to } \\
2.0 \mathrm{~V} \text { at } \\
0.2 \mathrm{C}\end{array}$ & $\begin{array}{c}712 \text { after } 50 \\
\text { cycles }\end{array}$ & $\begin{array}{c}82 . \\
0 / \\
80 . \\
5 / 7 \\
9.8\end{array}$ & $\begin{array}{c}816 \text { at } 0.1 \mathrm{C} \\
746 \text { at } 0.5 \mathrm{C} \\
723 \text { at } 1 \mathrm{C} \\
661 \text { at } 5 \mathrm{C}\end{array}$ \\
\hline $\begin{array}{l}\text { Ball milling+ } \\
\text { Spray drying + } \\
\text { CVD } \\
\text { Ref. } 23\end{array}$ & Nanoparticle & 12.5 & 4.1 & - & $\begin{array}{c}1 \mathrm{M} \mathrm{LiPF}_{6} \text { in } \\
\mathrm{EC}^{-} \mathrm{DMC} / \mathrm{DEC} \\
(1: 1: 1, \mathrm{v} / \mathrm{v} / \mathrm{v})+5 \% \\
\mathrm{FEC}\end{array}$ & $90: 5: 5$ & $\begin{array}{l}1.91 \text { after } \\
500 \text { cycles }\end{array}$ & $\begin{array}{c}0.005 \text { to } \\
1.0 \mathrm{~V} \text { at } \\
0.5 \mathrm{C}\end{array}$ & $\begin{array}{c}465 \text { after } 500 \\
\text { cycles }\end{array}$ & $\begin{array}{c}91 . \\
4\end{array}$ & $\begin{array}{l}610 \text { at } 0.5 \mathrm{C} \\
600 \text { at } 1 \mathrm{C} \\
580 \text { at } 2 \mathrm{C} \\
496 \text { at } 5 \mathrm{C}\end{array}$ \\
\hline
\end{tabular}




\begin{tabular}{|c|c|c|c|c|c|c|c|c|c|c|c|}
\hline $\begin{array}{c}\text { Hard and soft } \\
\text { template+CV } \\
\text { D+physical } \\
\text { blending } \\
\text { Ref. } 24\end{array}$ & Nanoparticle & 44.5 & 3 & - & $\begin{array}{l}1 \mathrm{M} \mathrm{LiPF}_{6} \text { in } 1: 1 \\
(\mathrm{v} / \mathrm{v}) \mathrm{EC} / \mathrm{DEC}\end{array}$ & $92: 5: 3$ & - & $\begin{array}{c}0.02-1.2 \\
\text { at } 0.1 \mathrm{C} \\
\text { with } \\
\mathrm{CCCV} \\
\text { step }\end{array}$ & $\begin{array}{c}600 \text { at first } \\
\text { cycle }\end{array}$ & 72 & $\begin{array}{c}450 \text { at } \\
500 \mathrm{~mA} \mathrm{~g}^{-1}\end{array}$ \\
\hline $\begin{array}{l}\text { Solution } \\
\text { based+ } \\
\text { Physical } \\
\text { blending } \\
\text { Ref. } 25\end{array}$ & Nanoparticle & $10 / 50$ & $6.2 / 1.1$ & - & $\begin{array}{l}1 \mathrm{M} \mathrm{LiPF}_{6} \text { in } 1: 1 \\
\text { (v/v) EC/DEC + } 5 \\
\mathrm{v} \% \text { FEC }\end{array}$ & $\begin{array}{c}\text { 80:10:10/80: } \\
20 / 00\end{array}$ & $\begin{array}{l}2.29 / 0.65 \\
\text { after } \\
125 / 300 \\
\text { cycles }\end{array}$ & $\begin{array}{c}0.01-1.0 \\
\mathrm{~V} \text { at } \\
0.6 / 0.5 \mathrm{C}\end{array}$ & $\begin{array}{c}369 \text { after } \\
125 / 594 \text { after } \\
300 \text { cycles }\end{array}$ & $\begin{array}{l}78 / \\
90\end{array}$ & 300 at $4 \mathrm{C}$ \\
\hline $\begin{array}{l}\text { Annealing } \\
\text { Ref. } 26\end{array}$ & Nanoparticle & $5-50$ & 2 & - & $\begin{array}{l}1 \mathrm{M} \mathrm{LiPF}_{6} \text { in } \\
\mathrm{EC} / \mathrm{DEC}+5 \mathrm{~V} \% \\
\mathrm{FEC}\end{array}$ & $80: 10: 10$ & - & $\begin{array}{c}0.01-2.0 \\
\mathrm{~V} \text { at } 50, \\
100,200, \\
500 \text { and } \\
1000 \mathrm{~mA} \\
\mathrm{~g}^{-1} .\end{array}$ & $\begin{array}{c}294,365, \\
676, \text { and } 269 \\
\text { with } 5,10, \\
25 \text { and } 50 \% \\
\text { of } \mathrm{Si} \\
\text { respectively } \\
\text { after } 100 \\
\text { cycles }\end{array}$ & 83 & $\begin{array}{c}980 \text { at } \\
50 \mathrm{~mA} \mathrm{~g}^{-1} \\
960 \text { at } \\
100 \mathrm{~mA} \mathrm{~g}^{-1} \\
890 \text { at } \\
200 \mathrm{~mA} \mathrm{~g}^{-1} \\
705 \text { at } \\
500 \mathrm{~mA} \mathrm{~g}^{-1} \\
610 \text { at } \\
1 \mathrm{~A} \mathrm{~g}^{-1}\end{array}$ \\
\hline $\begin{array}{c}\text { Annealing+Etc } \\
\text { hing+Milling } \\
\text { Ref. } 27\end{array}$ & $\begin{array}{l}\text { Nano/micro- } \\
\text { porous } \\
\text { particles }\end{array}$ & 10 & 11.2 & - & $\begin{array}{l}1 \mathrm{M} \mathrm{LiPF}_{6} \text { in } 1: 1 \\
(\mathrm{v} / \mathrm{v}) \mathrm{EC} / \mathrm{DEC}+10 \\
\mathrm{wt} \% \mathrm{FEC}\end{array}$ & $85: 3: 12$ & 5.2 & $\begin{array}{l}0.01-2.0 \\
\mathrm{~V} \text { at } 225 \\
\mathrm{~mA} \mathrm{~g}^{-1}\end{array}$ & $\begin{array}{c}460 \text { after } 115 \\
\text { cycles }\end{array}$ & 80 & - \\
\hline
\end{tabular}


Table S5: Full cell electrode and cycling information - with prelithiation

\begin{tabular}{|c|c|c|}
\hline \multicolumn{3}{|c|}{ Electrode information - with prelithiation } \\
\hline \multirow{2}{*}{ Electrode area $\left(\mathrm{cm}^{2}\right)$} & \multicolumn{2}{|c|}{1.1304} \\
\hline & Gt-SiNW & NMC \\
\hline Mass loading level $\left(\mathrm{mg} \mathrm{cm}^{-2}\right)$ & 4.58 & $15-16$ \\
\hline $\begin{array}{l}\text { Thickness including current } \\
\text { collector }(\mu \mathrm{m})\end{array}$ & 62 & 70 \\
\hline Electrode density $\mathrm{g} \mathrm{cm}^{-3}$ & 1.2 & 2.0 \\
\hline \multicolumn{3}{|c|}{ Full-cell information - with prelithiation } \\
\hline \multicolumn{3}{|c|}{$1^{\text {st }}$ cycle } \\
\hline \multicolumn{2}{|c|}{$\begin{array}{l}\text { Initial Coulombic efficiency }(\%) \\
\text { formation cycle }\end{array}$} & 88.4 \\
\hline Coulombic efficiency at first cycle $(\%)$ & & 99.4 \\
\hline Average voltage $(\mathrm{V})$ & & 3.76 \\
\hline Capacity (mAh) & & 2.96 \\
\hline \multicolumn{2}{|c|}{\begin{tabular}{|l|l} 
Gravimetric energy density $\left(\mathrm{Wh} \mathrm{kg}^{-1}\right)$ & \\
\end{tabular}} & 414 \\
\hline \multicolumn{3}{|c|}{$100^{\text {th }}$ cycle } \\
\hline Average voltage (V) & \multicolumn{2}{|r|}{3.76} \\
\hline Capacity (mAh) & \multicolumn{2}{|r|}{1.98} \\
\hline Coulombic efficiency (\%) & \multicolumn{2}{|r|}{99.9} \\
\hline
\end{tabular}

Table S6: Full cell electrode and cycling information - without prelithiation

\begin{tabular}{|c|c|c|}
\hline \multicolumn{3}{|c|}{ Electrode information - without prelithiation } \\
\hline \multirow[t]{2}{*}{ Electrode area $\left(\mathrm{cm}^{2}\right)$} & \multicolumn{2}{|c|}{1.5394} \\
\hline & Gt-SiNW & NMC \\
\hline Mass loading level $\left(\mathrm{mg} \mathrm{cm}^{-2}\right)$ & 2.82 & $15-16$ \\
\hline $\begin{array}{l}\text { Thickness including current } \\
\text { collector }(\mu \mathrm{m})\end{array}$ & 45 & 70 \\
\hline Electrode density $\mathrm{g} \mathrm{cm}^{-3}$ & 1.0 & 2.0 \\
\hline \multicolumn{3}{|c|}{ Full-cell information - without prelithiation } \\
\hline \multicolumn{3}{|c|}{$1^{\text {st }}$ cycle } \\
\hline Initial Coulombic efficiency (\%) & \multicolumn{2}{|r|}{58.0} \\
\hline Coulombic efficiency at first cycle $(\%)$ & \multicolumn{2}{|r|}{89.28} \\
\hline Average voltage $(\mathrm{V})$ & \multicolumn{2}{|r|}{3.54} \\
\hline Capacity (mAh) & \multicolumn{2}{|r|}{1.88} \\
\hline Gravimetric energy density $\left(\mathrm{Wh} \mathrm{kg}^{-1}\right)$ & \\
\hline \multicolumn{2}{|c|}{$100^{\text {th }}$ cycle } & 306 \\
\hline Average voltage $(\mathrm{V})$ & \multicolumn{2}{|r|}{3.51} \\
\hline Capacity (mAh) & \multicolumn{2}{|r|}{1.23} \\
\hline Coulombic efficiency (\%) & \multicolumn{2}{|r|}{99.9} \\
\hline
\end{tabular}


Estimation of gravimetric energy density

Gravimetric energy density $\left(\mathrm{Wh} \mathrm{kg}^{-1}\right)$

$$
=\frac{(\text { cell capacity }) \times(\text { average voltage })}{(\text { electrode area }) \times(\text { loading level of cathode and anode })}
$$

